\title{
Individual dispersal, landscape connectivity and ecological networks
}

\author{
Michel Baguette ${ }^{1,2, *}$, Simon Blanchet ${ }^{2}$, Delphine Legrand ${ }^{2}$, Virginie M. Stevens ${ }^{2}$ \\ and Camille Turlure ${ }^{3}$ \\ ${ }^{1}$ Muséum National d'Histoire Naturelle, UMR 7205 CNRS-MNHN-UPMC Origine, Structure et Evolution de la Biodiversité, F-75005 \\ Paris, France \\ ${ }^{2}$ USR CNRS 2936, Station d'Ecologie Expérimentale du CNRS à Moulis, 2 route du CNRS, F-09200 Saint Girons, France \\ ${ }^{3}$ F.R.S.-FNRS, Universite Catholique de Louvain, Earth and Life Institute, Biodiversity Research Centre, Croix du Sud 4, B-1348 \\ Louvain-la-Neuve, Belgium
}

\begin{abstract}
Connectivity is classically considered an emergent property of landscapes encapsulating individuals' flows across space. However, its operational use requires a precise understanding of why and how organisms disperse. Such movements, and hence landscape connectivity, will obviously vary according to both organism properties and landscape features. We review whether landscape connectivity estimates could gain in both precision and generality by incorporating three fundamental outcomes of dispersal theory. Firstly, dispersal is a multi-causal process; its restriction to an 'escape reaction' to environmental unsuitability is an oversimplification, as dispersing individuals can leave excellent quality habitat patches or stay in poor-quality habitats according to the relative costs and benefits of dispersal and philopatry. Secondly, species, populations and individuals do not always react similarly to those cues that trigger dispersal, which sometimes results in contrasting dispersal strategies. Finally, dispersal is a major component of fitness and is thus under strong selective pressures, which could generate rapid adaptations of dispersal strategies. Such evolutionary responses will entail spatiotemporal variation in landscape connectivity. We thus strongly recommend the use of genetic tools to: (i) assess gene flow intensity and direction among populations in a given landscape; and (ii) accurately estimate landscape features impacting gene flow, and hence landscape connectivity. Such approaches will provide the basic data for planning corridors or stepping stones aiming at (re)connecting local populations of a given species in a given landscape. This strategy is clearly species- and landscape-specific. But we suggest that the ecological network in a given landscape could be designed by stacking up such linkages designed for several species living in different ecosystems. This procedure relies on the use of umbrella species that are representative of other species living in the same ecosystem.
\end{abstract}

Key words: biodiversity, biological conservation, extinction, gene flow, population isolation, habitat selection, individual fitness, ideal free distribution, linkage strategy, landscape, seascape, water basin, functional connectivity, structural connectivity, landscape fragmentation, landscape genetics, umbrella species.

\section{CONTENTS}

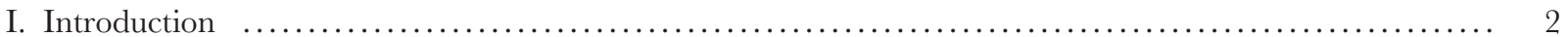

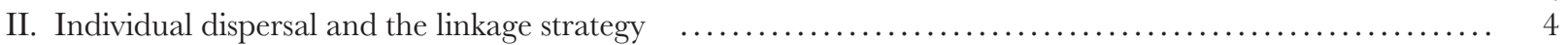

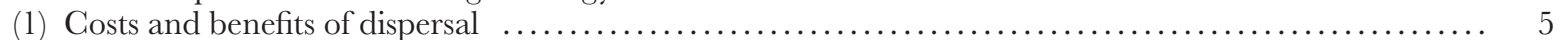

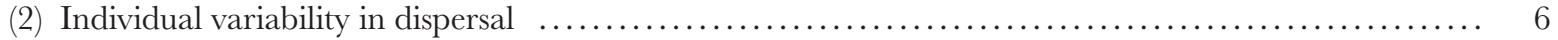

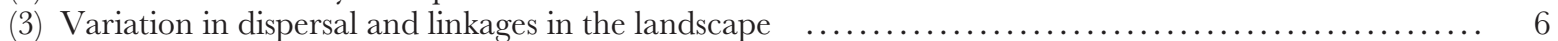

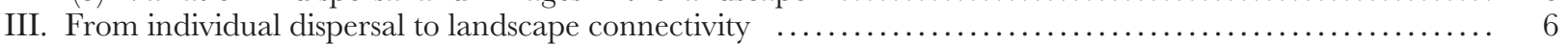

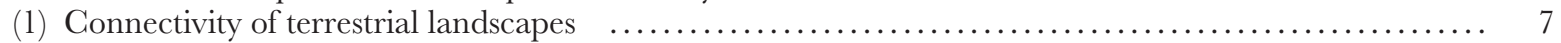

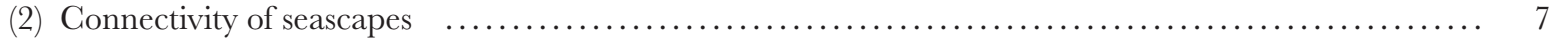

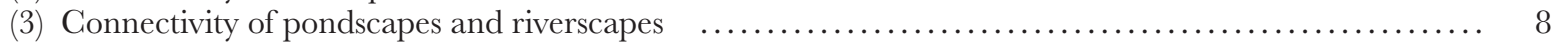

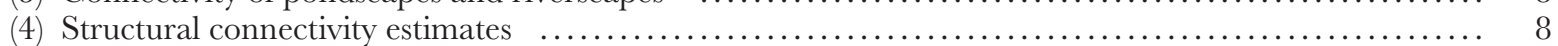

* Address for correspondence (Tel: ++33 561040380; Fax: ++33 561960851; E-mail: baguette@mnhn.fr). 


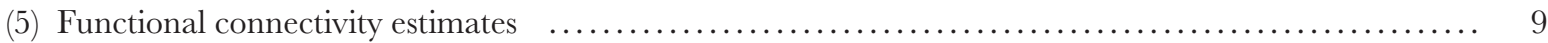

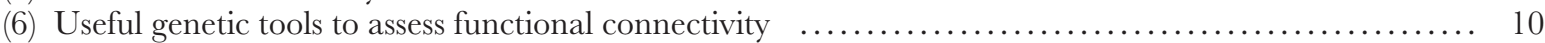

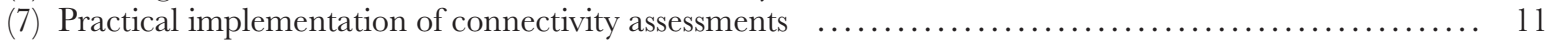

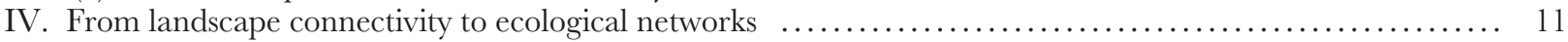

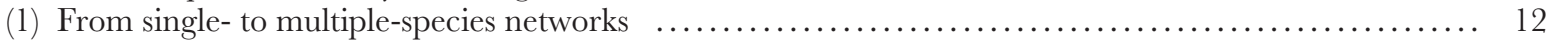

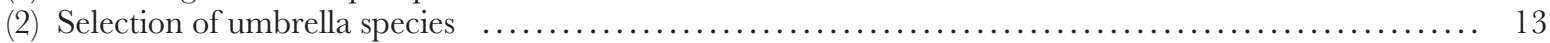

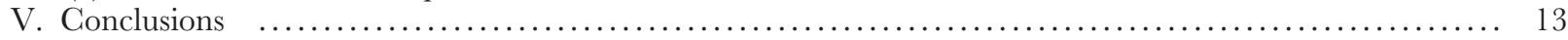

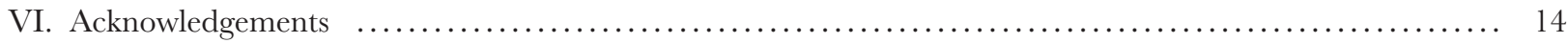

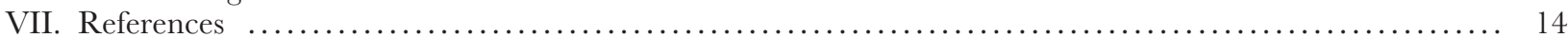

\section{INTRODUCTION}

Current massive species extinctions highlight how human activities negatively impact biodiversity worldwide (Pimm et al., 1995; Rockstrom et al., 2009; Pereira et al., 2010). Among the manifold pressures inflicted by Homo sapiens on other living organisms, the destruction of natural ecosystems is undoubtedly one of the major causes of biodiversity loss due to the resulting habitat loss and fragmentation (Vitousek et al., 1997; Pimm \& Raven, 2000; Foley et al., 2005; Lawler et al., 2006). Theory predicts and empirical studies confirm that both habitat loss and fragmentation contribute to local population extinctions (Fahrig, 2003; Ewers \& Didham, 2006; Swift \& Hannon, 2010). The extinction of a species is indeed usually preceded by the fragmentation and the shrinking of its distribution area, which reflects the progressive disappearance of local populations (Ceballos \& Ehrlich, 2002).

By removing suitable resources, habitat loss directly affects the carrying capacity of a given area, and hence its ability to sustain large populations, while small populations are more vulnerable to genetic, demographic and environmental accidents. Low effective population sizes decrease the genetic variability in populations and hence their adaptability to environmental changes [the extinction vortex (terms in italic throughout this review are defined in Table 1); Gilpin \& Soule (1986) and Fagan \& Holmes (2006)]. Both empirical (e.g. Saccheri et al., 1998) and experimental studies (e.g. Madsen et al., 1999) document the harmful interactions between genetic diversity and demographic stochasticity, dooming local populations to extinction. Some exceptions to this rule have been documented, particularly regarding the importance of the loss of genetic diversity associated with inbreeding (Reed, 2010). However, a vast majority of empirical studies confirm that the probability of extinction of a local population is positively related to its isolation, and negatively related to its size (e.g. Ouborg, 1993; Pimm et al., 1993; Hanski, 1999b; Brook et al., 2002; Rodriguez \& Delibes, 2003). Besides such local processes, the loss of habitat associated with fragmentation also increases the distances among suitable habitat patches, which in turn decreases the settlement probability of immigrants. The resulting functional isolation of local populations reduces both the rescue of imperiled populations (the rescue effect, Brown \& Kodric-Brown, 1977) and the rate of (re)colonization of vacant habitats (Hanski, 1998, 1999b), which should result in wider-scale species extinctions.
The best way to curb such extinctions would be to increase the carrying capacity of local populations, by increasing either the habitat area (Hodgson et al., 2011a) or the habitat quality. Implicit to the first possibility, the re-allocation of large areas to nature is rarely an option in heavily humandominated landscapes. Improving habitat quality is feasible for those few species for which ecological requirements are sufficiently well known, but often demands extensive man-power and hence high financial support. In addition, as habitat quality is species-specific and even populationspecific (e.g. Turlure et al., 2009), targeted conservation efforts may prove to be detrimental to other species of the same community.

An alternative (or complementary) strategy would be to increase the exchange of individuals among local populations, to reduce their functional isolation. These exchanges would facilitate the maintenance of large metapopulations (e.g. Levins, 1969; Hanski \& Gilpin, 1991, 1997; Hanski, 1998, $1999 b$ ) defined as groups of local populations where the movement of individuals among habitat patches is possible (Hanski \& Simberloff, 1997). In addition to their demographic effects [rescue and (re)colonization], movements of individuals among local populations may increase the genetic mixing among populations, hence reducing possible genetic variability erosion and thereby genetic diversity within populations, in turn sheltering these populations from extinction.

The metapopulation concept thus provides a solid framework for the conservation of species in heavily fragmented landscapes. In our vision of such spatially structured populations, local populations (demes) occupy habitat patches more or less isolated from each other in a matrix of more or less sub-optimal habitats. By explicitly considering that the matrix is composed of different elements with different quality, such structures do not correspond to the binary representation of landscape composed of suitable habitats embedded in an uniformly unsuitable matrix typical of the classical metapopulation theory. Our vision of metapopulations rather integrates insights from landscape ecology into metapopulation theory, as advocated by Wiens (1997).

The linkage strategy, corollary of the metapopulation theory, is an appealing methodology in conservation planning that aims to facilitate the displacements of individuals among local populations, either by the creation of corridors or stepping stones that bind local habitat patches into functional ecological networks (e.g. Beier \& Noss, 1998; Bennett, 1999; Jongman \& 
Table 1. Definition of terms in italic in the main text

\begin{tabular}{|c|c|}
\hline Term & Definition \\
\hline Dispersal & $\begin{array}{l}\text { Any movement of individuals or propagules with potential consequences for gene flow across space } \\
\text { (Ronce, 2007) }\end{array}$ \\
\hline Dispersal kernel & The probability density function that dispersing individuals move a certain distance \\
\hline Ecological network & $\begin{array}{l}\text { Set of suitable habitats and linkages (corridors, stepping stones) that allows the persistence of a viable } \\
\text { metapopulation }\end{array}$ \\
\hline Efficient connectivity & $\begin{array}{l}\text { Ultimate measure of landscape connectivity which evaluates the amount of gene flow across the } \\
\text { landscape }\end{array}$ \\
\hline Extinction vortex & $\begin{array}{l}\text { Suite of insidious reinforcement among biotic and abiotic processes following population decline } \\
\text { (environmental and demographic stochasticity, inbreeding) driving population size downward to } \\
\text { extinction (Gilpin \& Soule, 1986; Fagan \& Holmes, 2006) }\end{array}$ \\
\hline Friction map & $\begin{array}{l}\text { Layer in a geographical information system that indicates the costs that the different ecosystems of the } \\
\text { landscape will impose on a dispersing individual }\end{array}$ \\
\hline Functional connectivity & See landscape connectivity \\
\hline Functional habitat & $\begin{array}{l}\text { Set of resources that allows the completion of the life cycle of a given organism (e.g. Dennis, Shreeve \& } \\
\text { Van Dyck, 2003, Turlure et al., 2009) }\end{array}$ \\
\hline Graph theory & $\begin{array}{l}\text { Mathematical structures used to model pairwise relationships between habitats. A 'graph' is created of a } \\
\text { collection of 'nodes' (habitat patches) and a collection of edges (corridors) that connect pairs of } \\
\text { habitat patches (Urban \& Keitt, 2011) }\end{array}$ \\
\hline Habitat quality & $\begin{array}{l}\text { Ability of the environment to provide conditions appropriate for individual and population persistence } \\
\text { (Hall et al., 1997) }\end{array}$ \\
\hline Habitat selection & Behavioural process by which a given individual selects its functional habitat (Stamps, 2001) \\
\hline Hanski connectivity index & $\begin{array}{l}\text { For a landscape of } i+j \text { patches, } S_{\mathrm{i}} \text {, the connectivity of patch } i \text {, is computed as } S_{\mathrm{i}}(t)=\sum_{\mathrm{j} \neq \mathrm{i}} e^{-\alpha a_{\mathrm{ij}}} A_{\mathrm{j}} \\
\text { where } t \text { is time, } \alpha \text { is a constant setting the survival of dispersing individuals over } a_{\mathrm{ij}} \text {, the distance } \\
\text { between patch } i \text { and patch } j \text {, and } A_{\mathrm{j}} \text { is the area of the patch } j \text { (Hanski, 1999a) }\end{array}$ \\
\hline Ideal free distribution & $\begin{array}{l}\text { Theoretical concept that assumes that individuals move freely between habitat patches so as to } \\
\text { maximise their fitness (Fretwell \& Lucas, 1970). Dispersal has been proposed to distribute individuals } \\
\text { such that they achieve the same fitness (McPeek \& Holt, 1992), thus leading to an ideal free } \\
\text { distribution of individuals across space }\end{array}$ \\
\hline Landscape & $\begin{array}{l}\text { According to biogeography, an area showing homogenous geomorphological and climatic conditions } \\
\text { (Blondel, 1987) }\end{array}$ \\
\hline Landscape connectivity & $\begin{array}{l}\text { Degree to which the landscape facilitates or impedes movement among resource patches. The } \\
\text { landscape connectivity includes both structural connectivity, i.e. the physical relationships between } \\
\text { habitat patches (physical distances), and functional connectivity, i.e. an organism's behavioural response } \\
\text { to both the landscape structure and the landscape matrix (Taylor et al., 1993, 2006) }\end{array}$ \\
\hline Landscape genetics & $\begin{array}{l}\text { Discipline that investigates the contemporary processes affecting patterns of genetic variation across } \\
\text { natural environments (Manel et al., 2003) }\end{array}$ \\
\hline Least cost path modelling & $\begin{array}{l}\text { Method used for measuring the effective distance, rather than the Euclidian distance, between habitat } \\
\text { patches. Typically, a resistance map is the input to least-cost modelling. The algorithm computes the } \\
\text { route(s) with minimal costs that connect pairs of habitat patches (Adriaensen et al., 2003). Least cost } \\
\text { path models rely on the implicit assumption that dispersing individuals have total knowledge of the } \\
\text { landscape }\end{array}$ \\
\hline Linkage strategy & $\begin{array}{l}\text { Methodology aimed at increasing the connectivity between patches and hence facilitating the } \\
\text { displacements of individuals among local populations (Bennett, 1999) }\end{array}$ \\
\hline Matrix & In classical metapopulation theory, all ecosystems in the landscape that are not habitat patches \\
\hline Metapopulation & $\begin{array}{l}\text { Systems of local populations in discrete habitat patches that interact via dispersal of individuals moving } \\
\text { in the matrix. Such systems are buffered against extinction by gene flow among local populations, } \\
\text { rescue effects or recolonisation after local extinction }\end{array}$ \\
\hline Pondscape & Equivalent of landscape for lentic ecosystems \\
\hline Phylogeography & $\begin{array}{l}\text { Discipline which investigates the historical processes affecting patterns of genetic variation across } \\
\text { natural environments (Knowles, 2009) }\end{array}$ \\
\hline Resistance map & See friction map \\
\hline Riverscape & Equivalent of landscape for lotic ecosystems \\
\hline Seascape & Equivalent of landscape for marine ecosystems \\
\hline Stepping stones & $\begin{array}{l}\text { Small patches of habitat that are too small to support a viable population, but where dispersing } \\
\text { individuals can stop-over }\end{array}$ \\
\hline Structural connectivity & See landscape connectivity \\
\hline Umbrella species & $\begin{array}{l}\text { Species selected on the assumption that they are representative of the ecosystem in which they live. The } \\
\text { conservation actions that promote the persistence of umbrella species in the landscape must also } \\
\text { promote the persistence of (many, if not all) other species of the ecosystem (Caro et al., 2005) }\end{array}$ \\
\hline
\end{tabular}


Pungetti, 2004; Crooks \& Sanjayan, 2006; Hilty, Lidicker \& Merenlender, 2006; Baguette \& Van Dyck, 2007; Sawyer, Epps \& Brashares, 2011). The efficiency of the linkage strategy in increasing metapopulation persistence has been questioned repeatedly (e.g. Simberloff et al., 1992; Burkey, 1997; Hodgson et al., 2011b). However, theory predicts (Hanski, 1999b), and empirical studies, reviews and metaanalyses confirm, that movements of individuals among local populations increase metapopulation persistence (e.g. Beier \& Noss, 1998; Griffen \& Drake, 2008; Stevens \& Baguette, 2008; Gilbert-Norton et al., 2010; Doerr, Barrett \& Doerr, $2011 a)$.

As conservation biologists, building functional ecological networks that shelter the metapopulation of a given species from extinction in a given landscape is our ultimate goal, a goal that needs a subtle blend of two ingredients: habitat patches of sufficient high-quality and, simultaneously, efficient linkages allowing individual transfers among these habitats. Definitions of habitat quality and linkages mainly depend on habitat selection and dispersal, respectively, which unfortunately are markedly separated fields in the scientific literature, despite being conceptually strongly related (Chetkiewicz, Clair \& Boyce, 2006; Clobert, De Fraipont \& Danchin, 2008). Here, our discussion will mostly be centred on dispersal and the linkage strategy. Habitat selection will not be a focus, however, we acknowledge that the study of habitat selection, i.e. the preference of individuals for certain habitats, is essential to most conservation strategies, both by allowing the precise definition of habitat quality (e.g. Turlure et al., 2009), and by determining how individuals will move in the landscape. We suggest that habitat selection should not be considered only as a species-specific feature. Indeed, dispersing individuals of the same species will select different places to settle according to their particular phenotypes; this 'habitat-matching' process clearly influences how and where individuals disperse within metapopulations (Edelaar, Siepielski \& Clobert, 2008). There is thus a need to integrate habitat quality and linkages in future research.

For terrestrial ecosystems, the appropriate spatial scale for the deployment of functional ecological networks is the landscape. We introduce here the corresponding seascape, pondscape and riverscape in marine and freshwater (lentic and lotic) environments, respectively. For the sake of concision, we will use landscape as a generic term covering these four appellations, but we will address the particularities of each of these environments when relevant. There is a long history of controversies regarding the suitability and accuracy of landscape as a biological scale of investigation in ecology, leading to some paroxysmal declaration [e.g. 'The landscape level is dead: persuading the family to take it off the respirator' (Allen, 1998)]. We think that these controversies reflect the existence of two extreme conceptions of the landscape that are rooted either in biogeography or in behavioural ecology. According to biogeography, the landscape is a clearly defined level of organization, like regions or continents. The landscape is an area of space showing homogeneous geomorphology and climate (including water currents and flow regimes for seascapes, pondscapes and riverscapes), and its spatial scale is thus delineated using criteria external to the biota (e.g. Pickett \& White, 1985; Blondel, 1987). In behavioural ecology, the landscape is defined following the individual's own perception of its environment, and its spatial scale depends on the lifetime track of the organism under investigation (Baker, 1978; Nathan et al., 2008). As a result, with this definition, the spatial scale of landscapes is variable from one organism to the next. Here, we adopt the first conception, i.e. landscapes defined using geomorphological and climatic criteria correspond to mosaics of habitats organized along environmental gradients including ecological successions, which offer discrete patches with similar environmental conditions. In such landscapes, individuals will select habitats according to their ecological needs, local populations will thus establish in more or less discrete patches, and metapopulation functioning will emerge on a tractable scale. In addition to this, biogeographical landscapes most often correspond to homogeneous areas or zones regarding human activities like land use (residential, industrial, etc.), shipping, harvesting practices (agro-pastoralism, forestry, fisheries, etc.), and hence can be translated easily into administrative entities to facilitate the implementation of the linkage strategy.

Improving linkages among habitats and local populations should be based on a detailed knowledge of the dispersal process in the species of interest, an essential but often neglected issue. Both dispersal and habitat selection involve individual variation in performances and in decisions, especially in mobile species. Identification of critical features of linkage habitat should hence be based on data from large samples of individuals, to cover the range of individual variation, and accurately estimate both the mean and the variance of dispersal and habitat selection. This approach thus requires multiple population-centred studies (Morris \& Diffendorfer, 2004; Morris, Diffendorfer \& Lundberg, 2004; Schtickzelle, Mennechez \& Baguette, 2006).

Here we start by reviewing whether current advances in dispersal theory could assist in the implementation of the linkage strategy. We then investigate the relationship between individual dispersal and landscape connectivity. Finally, we investigate how ecological networks could emerge from the linkage strategy within landscapes and the corresponding seascapes, pondscapes and riverscapes. We have adopted a general coverage of these issues, potentially applicable to both sessile and mobile organisms, and pointed out the differences between these two kinds of organisms when relevant.

\section{INDIVIDUAL DISPERSAL AND THE LINKAGE STRATEGY}

Dispersal, the movements of individuals or propagules that can sustain gene flow (Ronce, 2007), is a complex, multicausal process (see reviews in Clobert et al., 2001; Clobert, Ims \& Rousset, 2004; Matthysen, 2012), potentially leading to both fitness costs and benefits for dispersing individuals 


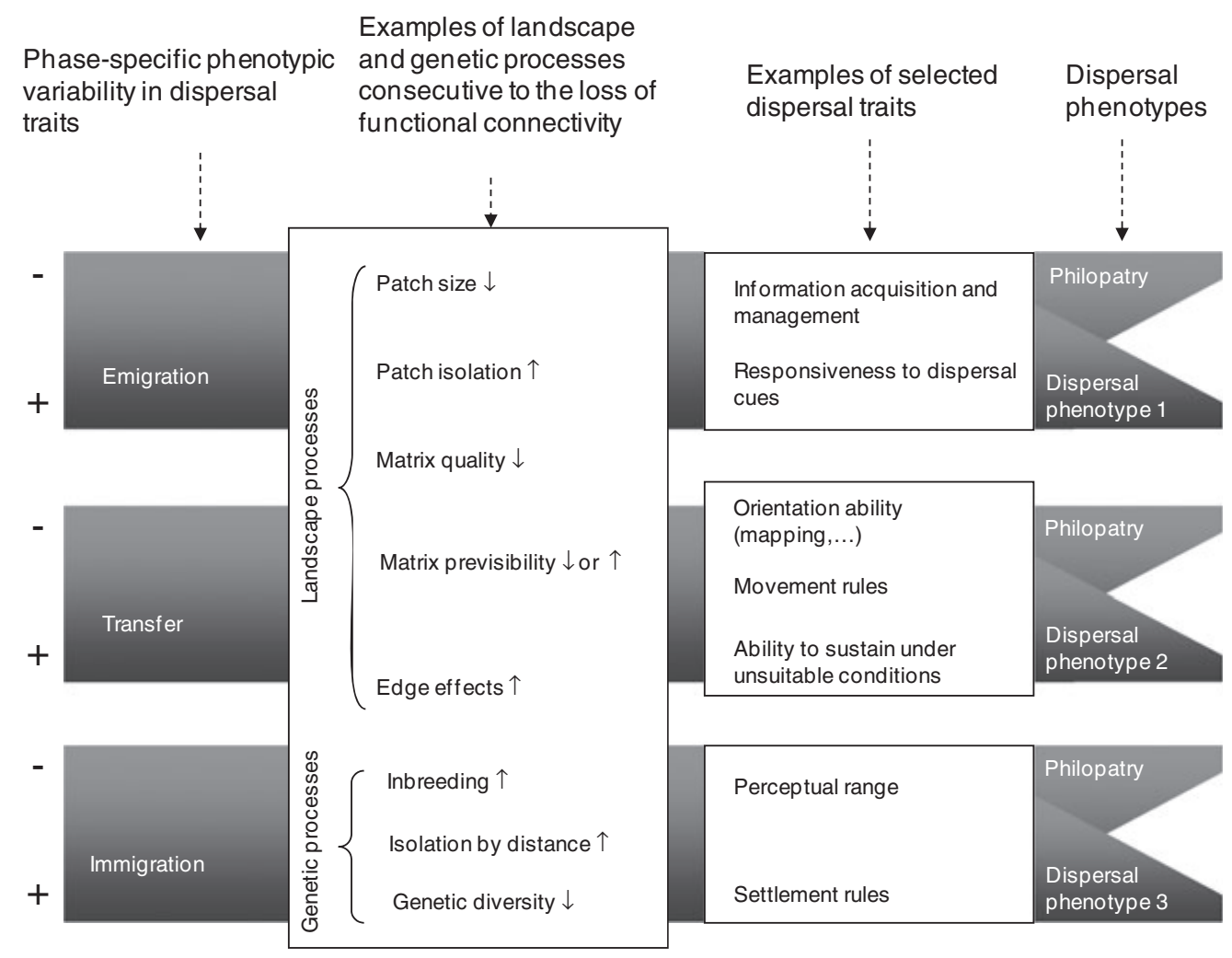

Fig. 1. Landscape/dispersal interactions can generate complex eco-evolutionary feedbacks. A loss of functional connectivity has consequences on both the structure of the landscape and the genetic structure of the local populations. Dispersal phenotypes 1,2 and 3 result from these interactions, with modifications on traits associated with each of the three phases of the dispersal process (emigration, transfer and immigration). Each of the three dispersal phenotypes may have a particular dispersal strategy.

(Clobert, De Fraipont \& Danchin, 2008; Bonte et al., 2012). To appraise the costs and benefits of dispersal fully, a convenient approach is to disentangle the process into three successive, but inter-related phases: departure out of a habitat, transfer within the landscape, and settlement and reproduction in a new habitat, which may or may not be occupied by conspecifics (Stenseth \& Lidicker, 1992; Ims \& Yoccoz, 1997; Bowler \& Benton, 2005; Baguette \& Van Dyck, 2007; Clobert et al., 2009; Bonte et al., 2012). Both the capacity and the decision to disperse are shaped by particular selective pressures potentially independent of each other (Fig. 1), while others, like parental effects during ontogeny, will constrain the whole dispersal process (Bonte et al., 2012; Ducatez et al., in press.

\section{(1) Costs and benefits of dispersal}

Among the multiple benefits of dispersal in heterogeneous environments, the most prominent are the avoidance of conspecific individuals (i.e. avoidance of kin competition, limitation of inbreeding) and the avoidance of variation in reproductive success associated with deteriorating environmental conditions, both with obvious direct consequences on individual fitness (Clobert et al., 2001). Density of kin or conspecific individuals is thus a sensible cue that may help mobile individuals to make the appropriate decision to leave a habitat patch before competition reaches a critical threshold threatening their fitness (e.g. Travis, Murrell \& Dytham, 1999). Sessile individuals are by definition immobile, but mothers can adapt the dispersal abilities of their offspring to the density of kin and conspecific individuals (e.g. Allen, Buckley \& Marshall, 2008).

Landscape fragmentation gives rise to dispersal costs by increasing the distances among habitat fragments (Fahrig, 2003; Kokko \& Lopez-Sepulcre, 2006; Schtickzelle et al., 2006; Bonte et al., 2012). Dispersing individuals have to travel longer distances across unsuitable parts of the landscape (the matrix), which requires time and energy and increases the risk of unsuccessful dispersal (Bonte et al., 2012). These costs often generate phenotypic responses that decrease dispersal propensity (the probability that an individual leaves a habitat), or that increase dispersal efficiency in decreasing the time spent in the matrix by changing morphological, behavioural or physiological attributes. This would eventually reduce dispersal costs either through a reduced search time or through the selection of relatively safe dispersal routes (e.g. Baguette \& Van Dyck, 2007; Schtickzelle et al., 2007; Delattre et al., 2010; Turlure et al., 2011). In passively dispersing organisms, where sensorymotor adaptations are obviously more difficult, the increasing dispersal costs due to landscape fragmentation may decrease the rate of successful dispersal, with the potential negative 
effects of increasing inbreeding depression (Bonte et al., 2012). Emigration and immigration rates are thus highly versatile parameters (e.g. Baguette, Clobert \& Schtickzelle, 2011), the ultimate criterion for their fine-tuning being the maximization of individual fitness eventually leading to an homogeneous distribution analogous to an ideal free distribution of fitness prospects of individuals among habitats (Holt \& Barfield, 2001; Morris et al., 2004; Clobert et al., 2008, 2009).

\section{(2) Individual variability in dispersal}

How individuals with different phenotypic attributes will map on a particular fitness landscape and what will be the resulting ideal distribution maximizing fitness is an appealing research question. In mobile animals, the dispersal tendency is often associated with behavioural traits like boldness, sociability or aggressiveness (Cote et al., 2010). These traits constitute real personality syndromes, i.e. the existence of consistent differences between individuals in their behaviours across time and contexts (Dingemanse et al., 2009), as they are expressed throughout the lifetime of the individual (Cote et al., 2010). Such inter-individual variability clearly merits strong attention for its impact on the spatial distribution of individuals.

Dispersal is a process occurring in the life cycle of most living organisms. However, its timing and frequency vary according to individual strategies of space use. The interplay between resource dynamics (i.e. spatiotemporal availability of resources) and the evolution of life-history traits has shaped contrasting spatial strategies that coexist both within and among species. Indeed, these strategies were initially introduced to compare species with different spatial behaviours. However, there is now compelling evidence that similar variations exist among individuals of the same species (e.g. Cote et al., 2010, for a review). In animals, we distinguish the two extremes of variation in these strategies; sedentary and nomadic individuals (Mueller \& Fagan, 2008). Sedentary individuals are those animals that spent most of their lifetime in the same area (home range or territory), in which they find all the resources required to complete their life cycle, including mates. Nomadic individuals are always on the move, constantly sampling the environment to acquire the resources they need. Note that an intermediate migratory state in which individuals perform regular movements (in response to periodic fluctuations in environmental conditions) is also described. In sedentary individuals, dispersal is a rare event that occurs usually during well-defined periods of the life cycle. In nomadic individuals, dispersal may occur at any time in the individual's life. This basic distinction in individuals' strategies of space use has fundamental consequences for the design of linkages in the landscape, as connecting structures should be much more robust for sedentary species than for nomads. Indeed, we expect that those nomadic individuals that need to be mobile to sustain their daily requirements will adapt one or several components of movement (motion or navigation capacity, movement decision, information acquisition and storage: Nathan et al., 2008) more rapidly to cope with higher dispersal costs in heavily fragmented landscapes.

\section{(3) Variation in dispersal and linkages in the landscape}

Dispersal is likely to vary among individuals but also during an individual's life because of phenotypic plasticity and/or ontogenic shift. Such inter- and intra-individual variability in dispersal must be included when considering linkages in landscapes. The intra- and inter-specific variations in dispersal that we briefly addressed above demonstrate the difficulty of implementing suitable corridors and stepping stones to provide functional ecological networks. For instance, dispersing individuals of mobile species may leave habitat patches of excellent quality or stay in habitat of poor quality according to local kin competition or excessive costs of dispersal, respectively (e.g. Boudjemadi, Lecomte \& Clobert, 1999; Schtickzelle et al., 2006). In such cases, habitat quality is obviously not a good predictor of dispersal. In addition, all individuals of a population do not necessarily react in the same way to those cues that trigger dispersal (inter-individual variation), sometimes shaping real dispersal strategies (e.g. Lepetz et al., 2009; Cote et al., 2010; Ronce \& Clobert, 2012). Such strategies even coexist within nomadic species (Legrand et al., 2012). Individuals with contrasting behavioural profiles, such as bold versus shy individuals (Wilson et al., 1994; Réale et al., 2000), may also have contrasting physiological and/or morphological capacities (Sinn, Apiolaza \& Moltschaniwskyj, 2006) that will constrain their movement capacity and hence their dispersal ability (Chapman et al., 2011). Theory predicts that dispersal evolution will depend on the fraction of suitable habitat in the landscape, the dispersive strategy is fixed when this fraction exceeds $75 \%$, whereas the resident strategy is fixed when this fraction drops below 15\% (see fig. 5 in Travis \& Dytham, 1999). Accordingly, we can expect that the connection of populations will influence the relative frequencies of dispersal strategies. How the linkage strategy will affect competition among these dispersal strategies and thus the frequencies of alternative individual profiles is an intriguing and topical research question.

\section{FROM INDIVIDUAL DISPERSAL TO LANDSGAPE GONNEGTIVITY}

The linkage strategy aims to build networks of habitats and populations interconnected by dispersing individuals within a given landscape. Dispersal of individuals is thus the key process that permits the functioning of such spatial networks. In landscape ecology and conservation biology literature, this functioning is usually expressed as landscape connectivity: the degree to which the landscape facilitates or impedes movement among resource patches (Taylor et al., 1993; Taylor, Fahrig \& With, 2006). For marine and freshwater ecosystems, we introduce the corresponding expressions 'seascape connectivity' and 'pondscape and 
riverscape connectivity' respectively, hereafter implicitly included when we use the generic expression 'landscape connectivity'. Shifting from dispersal to connectivity is more than a semantic issue: the focus shifts from individuals to landscapes. Connectivity is in fact a dynamic property of the landscape, resulting from both the dynamics of disturbances in the landscape and spatiotemporal variation in dispersal. If the dynamics of disturbances is a central tenet in ecology (e.g. Pickett \& White, 1985; Turner, 2000), its implications on connectivity by creating selective pressures on dispersal related to the location of suitable habitat patches remain largely unexplored. Theoretical studies show that the evolution of dispersal depends on both the spatiotemporal variation in the carrying capacity of local populations (e.g. McPeek \& Holt, 1992), and the number of habitat patches in the landscape, itself resulting from the dynamics of disturbances in the landscape (e.g. Travis \& Dytham, 1999). However, how these two factors interact according to landscape dynamics is a complex, and still unsolved issue. We thus note that for a given species, dispersal is contextdependent because it is constrained by the habitat dynamics for a given landscape.

More generally, connectivity is dependent on the physical medium (i.e. land, air, water) that dispersing individuals will have to cross. This leads us to explore below the particularity of the dispersal process, and its consequences on the connectivity of terrestrial landscapes, seascapes, pondscapes and riverscapes. Whatever the nature of the physical medium, two wide families of connectivity estimates are used (Calabrese \& Fagan, 2004). Structural connectivity estimates are based on the spatial arrangement of suitable habitat patches in the landscape, possibly combined with the mean dispersal ability of a focal species (potential connectivity). Functional connectivity estimates assess the net flow of individuals moving among habitat patches in the landscape.

\section{(1) Connectivity of terrestrial landscapes}

The terrestrial world is patchy at multiple spatial scales, due to multiple natural and anthropogenic ruptures of continuity (e.g. Forman \& Godron, 1986; Forman, 1995). Dispersing individuals using walking or crawling locomotory modes are thus confronted with physical barriers impeding their passage, or with landscape elements that are more or less easy to cross. The presence and the configuration of such structures in terrestrial landscapes can lead to anisotropic dispersal that is captured poorly by structural connectivity estimates (Baguette \& Van Dyck, 2007). The term landscape resistance has been coined to describe the cost that each landscape element will levy to dispersing individuals; in terrestrial ecology these costs have been estimated from expert advice (e.g. Verbeylen et al., 2003), modeled from presence/absence data, from density data (e.g. Coulon $e t$ al., 2004), from gene flow among local populations (e.g. Cushman et al., 2006) or experimentally assessed (e.g. Rothermel \& Semlitsch, 2002; Stevens et al., 2006). The landscape can then be portrayed as resistance maps, or friction maps, representing the cost of dispersal according to a given organism's perspective.

Individuals dispersing using airways (e.g. birds, pollen or seeds) are less directly dependent on the patchiness of the terrestrial world, but they are also confronted with a heterogeneous environment. Wind strength and direction, topography and temperature will indeed canalize the fluxes of individuals, leading to the existence of flyways analogous to corridors for walking or crawling organisms. Here again, the resulting anisotropy in dispersal will limit the use of simple structural connectivity estimates.

Estimating connectivity in the terrestrial world has practical applications in landscape planning and conservation biology, by assessing the effectiveness of management scenarios. The focus of studies using structural connectivity estimates is mainly the linkage of similar ecosystems in the landscape (e.g. Alagador et al., 2012), therefore making the implicit assumption that metapopulation functioning will emerge from such networks. Conversely, functional connectivity estimates are mainly used to design viable metapopulations of focal species (e.g. Stevens \& Baguette, 2008).

\section{(2) Connectivity of seascapes}

Many marine systems, such as kelp forests, estuaries, brackish waters, seagrass beds, coral and rocky reefs, and deep-sea hydrothermal vents, are naturally fragmented and patchy (DiBacco, Levin \& Sala, 2006). These systems are immersed in a medium showing complex tri-dimensional dynamics due to water currents and upwelling that both facilitate or impede movements of living organisms and generate heterogeneity in temperature, salinity, sediment load or light conditions. Seascapes can thus be viewed as networks of habitat patches within a heterogeneous environment in which species occur in discrete local populations connected by passive or active dispersal of individuals. In marine systems, dispersal in these metapopulations is realized either by early life stages such as larvae or spores (propagules), by juveniles, or by adults (DiBacco et al., 2006). The diversity of these dispersal stages combined with the diversity of nutritional modes, development sites, planktonic durations, and morphology clearly infers a seascape connectivity specific to the considered organism. Seascape connectivity has been used to propose networks of marine protected areas, which is an important issue in the context of overfishing and the conservation of sustainable marine resources (Pauly et al., 2002). These networks of marine protected areas function as source-sink systems by sending individuals into exploited areas; this strategy significantly increases not only the fishery value (Costello et al., 2010; Gaines et al., 2010), but also environmental and tourism values (McCook et al., 2010). The connectivity within and among such networks is usually assessed by structural connectivity estimates based on the current regime in the study area (Cowen, Paris \& Srinivasan, 2006; Sundblad, Bergström \& Sandström, 2011). However, studies of focal species using a functional connectivity approach with 'seascape genetics' show that 
different habitats impose different constraints on the mobility of moving individuals, as in terrestrial ecosystems (Bay, Caley \& Crozier, 2008; Turgeon et al., 2010; Hitt, Pittman \& Nemeth, 2011; Mokhtar-Jamai et al., 2011). Adding this resistance component to the current regime could provide more efficient estimates of seascape connectivity. Moreover, such studies have the potential to demonstrate unambiguously that the networks of marine protected areas ensure smooth metapopulation functioning for focal species (Teske et al., 2010), which is crucial for the sustainable sourcing of exploited areas.

\section{(3) Connectivity of pondscapes and riverscapes}

Fresh waters are diverse in their physical structures, and host both purely aquatic and semi-aquatic organisms; these two characteristics make the setting of a single definition of connectivity in such ecosystems unrealistic. Three main types [large lakes ('inland seas'), pond networks and river networks] will be briefly described here, with an emphasis on river networks.

Connectivity in lakes is similar to that defined for the seascape, and the network of heterogeneous habitat patches is both a cause and a consequence of important physical constraints such as wind, bottom flows, inlets, outlets, etc. Pond (or small lake) networks are similar to terrestrial landscapes, whereby favourable patches (ponds) are interconnected by well-defined corridors (permanent or non-permanent channels or streams) acting as dispersal pathways for purely aquatic organisms (Michels et al., 2001; Cottenie \& De Meester, 2003; Dahlgren \& Ehrlén, 2005). It is noteworthy that semi-aquatic organisms (amphibians, semi-aquatic invertebrates, etc.) can use alternative dispersal pathways (terrestrial habitat, airways) connecting metapopulations at a larger spatial scale, and sometimes creating unexpected and unpredictable metapopulation dynamics (Bilton, Freeland \& Okamura, 2001; Figuerola, Green \& Michot, 2005; Fortuna, GomezRodriguez \& Bascompte, 2006; Vanschoenwinkel et al., 2008).

Connectivity in river networks is very specific as it is constrained in a one-dimensional landscape by the longitudinal structure of the network (i.e. dendritic network, Campbell Grant, Lowe \& Fagan, 2007) and by the river flow that often constrains the dispersal of organisms to a downstream direction (Hänfling \& Weetman, 2006; Pollux et al., 2009). As such, the spatial dynamics of these metapopulations are often described as continuous source-sink dynamics whereby upstream populations serve as sources and downstream populations serve as sinks (Kawecki \& Holt, 2002; Morrissey \& de Kerckhove, 2009. From an ecological viewpoint, such an asymmetrical network makes colonization less likely and extinction more likely in upstream patches than in downstream patches (Gotelli \& Taylor, 1999). Similarly, the evolutionary dynamics of metapopulations in dendritic networks is supposed to be location specific since gene flow is mainly downstreamdirected, which should favour local adaptation upstream and maladaptation downstream (Kawecki \& Holt, 2002). Finally, connectivity per se also affects the dispersal of organisms in dendritic networks (Carrara et al., 2012; I. Paz-Vinas, G. Loot \& S. Blanchet, in preparation); headwaters are often distinct evolutionary populations whereas confluence patches are a genetic mix of several headwater patches, and hence reservoirs for genetic diversity. Confluence patches are therefore thought to be more stable, however headwater patches are the sources of diversity in a basin and therefore very important from a conservation viewpoint (Campbell Grant, Lowe \& Fagan, 2007). Such asymmetrical dynamics can be affected by natural and/or anthropogenic barriers such as waterfalls, riffles, weirs, dams or pollution (Dudgeon et al., 2006; Blanchet et al., 2010), particularly if the longitudinal dynamic is broken down and if dispersal and gene flow are affected. Many riverscape elements are accounted for when evaluating resistance to dispersal in rivers (Raeymaekers et al., 2009; Faulks, Gilligan \& Beheregaray, 2011). Riverscape connectivity is species-specific and highly contingent upon the dispersal ability of species: some will be able actively to overcome upstream-directed water flow through enhanced swimming ability (Blanchet et al., 2010) or through the use of terrestrial habitat or airways (Campbell Grant et al., 2010; $\mathrm{Alp}$ et al., 2012). In the latter case, dispersal is no longer constrained within watersheds. Recent studies demonstrated the importance of using non-aquatic dispersal corridors for understanding metapopulation dynamics at larger spatial scales, i.e. between adjacent or non-adjacent watersheds (Campbell Grant et al., 2010).

Estimates of connectivity in fresh waters have been valuable for conservation and restoration viewpoints. Specifically, estimating resistance costs is essential to prioritize anthropogenic elements to be cleared (Raeymaekers et al., 2009), and natural elements to be restored to ensure proper metapopulation dynamics in freshwater ecosystems (Faulks et al., 2011). Although an applied perspective of the metapopulation framework has been widely developed in river networks (notably through the use of genetic tools), studies on lake or pond networks remain scant. Similarly, such a framework now needs to be adjusted to establish efficient and effective protected areas, as it is classically done in terrestrial landscapes and seascapes.

\section{(4) Structural connectivity estimates}

The simplest structural connectivity estimate is the Euclidean distance among habitat patches or populations (edge to edge or centre to centre). Some refinements are found in graph-theory, the Hanski connectivity index and least cost path modeling which take into account the mean dispersal ability (MDA) of the species, the MDA combined with the distance and the area of habitat patches, and the resistance of different types of habitats in the landscape to individual movements, respectively. The relative efficiency of these estimators has been tested rarely (e.g. Moilanen \& Nieminen, 2002; Stevens et al., 2006; Baguette \& Van Dyck, 2007; Desrochers et al., 2011; Palmer, Coulon \& Travis, 2011; Sawyer et al., 2011), but a common risk associated with such 
simple estimates of connectivity is to end up with simple rules, such as 'patches isolated by less than a threshold distance or by a threshold of presumed costs are functionally connected, others are functionally isolated', a black-andwhite classification typically resulting, for instance, from a graph-theory analysis (Urban et al., 2009). The review of Sawyer et al. (2011) explores the limitations of least cost path modeling, which can be considered as the most refined structural connectivity estimate. These authors identify two major biases in published studies on animals: (i) the most current least cost path models ignore how animals actually utilize the landscape; and (ii) most models use coarse-grained environmental data layers to determine habitat connectivity, an approach that is often biased by researcher-perceived structural connectivity and runs the risk of missing important biological aspects. The latter bias is complicated further by the fact that although the scale of analysis has been shown greatly to impact the strength of detected relationships, study grain was typically dictated by the remote-sensing data available rather than by species perceptions of landscape features. Overall, the strength of the correlation between remotely sensed habitat layers and individual movement is relatively unknown and poorly validated (Sawyer et al., 2011).

The danger here is thus that the dispersal process is obviously too complex to be encapsulated into such simple estimates of connectivity. This problem was also identified as a limitation to the use of graph-theoretic connectivity in spatial ecology and conservation (Moilanen, 2011). As mentioned above, dispersal is spatiotemporally variable within metapopulations, a variation that is easily observed in ecological time, for instance, according to density (e.g. Travis et al., 1999; Matthysen, 2005) or to environmental changes (e.g. Kendall et al., 2000). Moreover, given its importance in shaping individual fitness (Holt \& Barfield, 2001; Morris et al., 2004; Clobert et al., 2008, 2009) and life histories (Stevens et al., 2012), dispersal is susceptible to rapid evolutionary adjustments to cope with directional selection pressures (Dytham, 2009; Burton, Phillips \& Travis, 2010). If a network is to be considered functional this variability of dispersal should be taken into account, and can be by using a functional approach to landscape connectivity.

\section{(5) Functional connectivity estimates}

How can one account for dispersal variability in connectivity estimates? Methods aimed at estimating dispersal are multiple, from the direct estimation of emigration and immigration to the indirect assessment of dispersal using estimates of gene flow, through the computation of dispersal kernels. In European butterflies, a homogeneous taxonomic group in which dispersal is particularly well informed both at the inter- and intra-specific level, a meta-analysis showed a relatively good congruence among these dispersal estimates (Stevens, Pavoine \& Baguette, 2010a; Stevens, Turlure \& Baguette, 2010b). The use of carefully parameterized individual-based models has also been proposed to infer functional connectivity estimates (e.g. Baguette \& Van Dyck, 2007). However, even if such models are highly flexible, their application to real situations requires extremely detailed data on the life history of the target organisms, including its variability, which are often not available.

Here we suggest that quantifying gene flow - and the barriers to gene flow- among local populations using genetic tools, and determining which elements of the landscape modulate these genetic exchanges among populations using landscape genetics provides one of the strongest frameworks for investigating landscape connectivity and its variability (e.g. Manel et al., 2010; Sork \& Waits, 2010). Indeed, the comparison between such measurements of the 'efficient connectivity' of the landscape and the movements of individuals among local populations can reveal additional information on the effect of landscape structure on the reproductive success of immigrants (Coulon et al., 2004; Vignieri, 2005; Stevens et al., 2006; Jaquiery et al., 2011; Mokhtar-Jamai et al., 2011; Legrand, Stevens \& Baguette, 2011a). If the immigrants' investment in the dispersal process is too high, they may lose the chance to reproduce in their new habitat (e.g. Parn et al., 2009). Accordingly, even if local populations are connected by frequent dispersal events, their genetic pool may remain isolated, leading to significant inbreeding, especially if the effective population size is small. In such cases, the improvement of connecting structures (either with corridors or stepping stones) could break this creeping isolation by limiting dispersal costs (Epps et al., 2007; Fig. 2). The effective dispersal/immigration ratio is thus a crucial parameter of landscape connectivity.

A reliable estimate of gene flow in a given landscape is the ultimate measurement of landscape connectivity. Genetic tools allow such estimates of gene flow, whereas landscape genetics allow determination of how different landscape elements modulate these genetic exchanges, by facilitating or impeding individual movements. Additionally, population genetics may help to distinguish among various different models of population structure [i.e. the island model, the stepping stone model, or the continuous model (Maynard Smith, 1989)] with contrasting assumptions (Broquet et al., 2006; Broquet \& Petit, 2009). The reverse, i.e. inferring gene flow from landscape connectivity, appears a more difficult task that often requires precise knowledge of both organism lifestyle and habitat characteristics (such as habitat suitability; Wang et al., 2008), which may be difficult to obtain for some organisms. One of the major advantages of using genetic tools to assess gene flow and infer the role of landscape features in the observed gene flow is the possibility to work at several spatial and temporal scales when required, provided that the right panel of genetic markers is used (Sunnucks, 2000; Zhang \& Hewitt, 2003). Contemporary processes are studied using population genetic methods while historical processes are investigated using phylogeography (Wang, 2010). Using nucleotide sequences (i.e. markers with a low mutation rate) in an endemic Drosophila species distributed across islands of the Seychelles archipelago, Legrand et al. (2009) showed that the biogeography of the region did not affect the genetic diversity and population structuring of the species. Using the same sample of individuals but genotyping microsatellites 


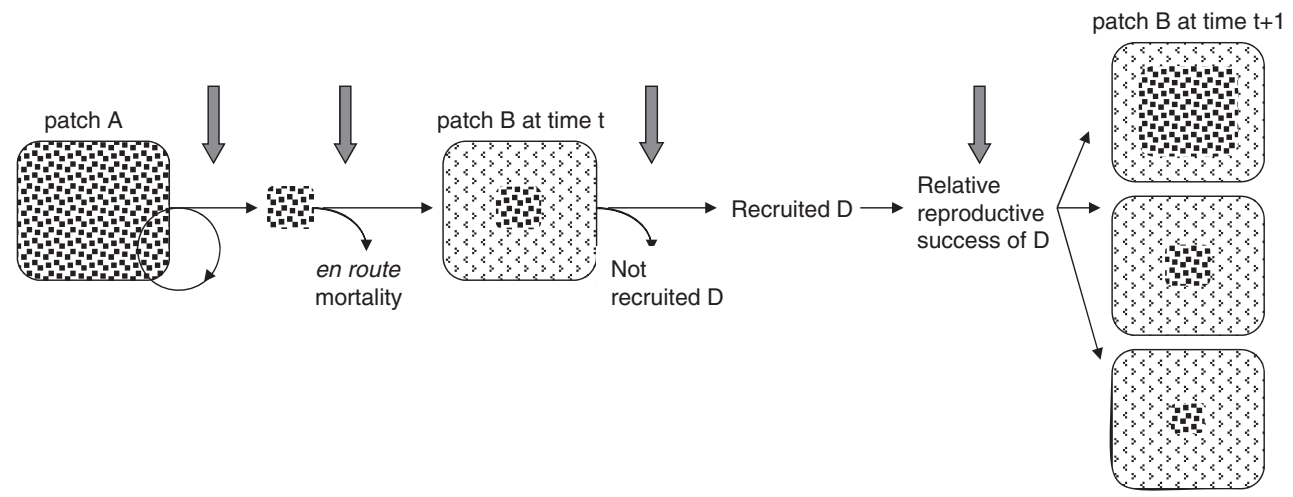

Fig. 2. Selective pressures on individuals during the dispersal process. Only a fraction of the population (D) decides to emigrate from patch $\mathrm{A}$; part of $\mathrm{D}$ died or was lost during transfer. After immigration into patch $\mathrm{B}$, a fraction of $\mathrm{D}$ is recruited into the reproductive population. According to the relative reproductive success of these individuals (as compared to individuals born in patch B), the genetic composition in patch B will be more or less affected (illustrated by background patterns). Grey vertical arrows indicate processes where natural selection, as well as conservation planning, may modify the gene flow between patches A and B.

(i.e. markers with a higher mutation rate), Legrand et al. $(2011 b)$ showed, by contrast, that gene flow was recently favoured between neighbouring islands, which resulted in the differentiation of two genetic groups. Thus, a clear distinction exists between past and current landscape effects on this species. This example illustrates how powerful the use of genetic inferences can be, from the n-1 generation before sampling (in Legrand et al., 2011b) to the speciation time in some cases (Legrand et al., 2009). Other examples illustrate the utility of using different markers to study the impact of landscape processes on flows of individuals at different temporal scales (Johnson, Toepfer \& Dunn, 2003; Lada, MacNally \& Taylor, 2008; Pease et al., 2009).

Genetic tools are a useful way to measure dispersal. Indeed, molecular markers can be used to study dispersal either indirectly, via allele distribution among populations, using population genetic models (Slatkin, 1987), or directly by the assignment of individuals to (at least one of) their parents or to their population of origin (Manel, Gaggiotti \& Waples, 2005). With direct methods, both non-effective and effective dispersal can be measured, while indirect methods can only measure effective dispersal. Current refinements to these methods (see section III.6), given an appropriate sampling design and the appropriate choice of molecular markers, permit the quantification of synthetic descriptors of dispersal, like dispersal rate and dispersal distance. Broquet \& Petit (2009) thoroughly reviewed the methods available for such calculations. They provide a very useful appendix with all the information required to make an appropriate choice for measuring dispersal using genetic data. Moreover they thoroughly discuss sampling issues associated with this technique, as well as the choice of molecular markers.

\section{(6) Useful genetic tools to assess functional connectivity}

Gene flow estimate is one central measure of population genetics studies. However, the methodology used to obtain the matrices of immigration/emigration between populations remains questionable. Indeed, most population genetics studies use $F_{s} t$ as a proxy of gene flow following $F s t=1 /(4 \mathrm{Nem}+1)$ where $\mathcal{N}$ is the effective population size and $m$ the rate of gene flow between populations (Wright, 1931). [Geneticists use the term migration to describe the processes leading to gene flow among populations. In ecology, these processes are termed dispersal while migration is usually restricted to periodic movements associated with the use of temporary but predictable resources.] The vast majority of population genetics studies however violate the assumptions of the underlying island model, which assumes, in particular, symmetrical gene flow and equal population sizes for all populations (Wright, 1931; see Whitlock \& McCauley, 1999, for further discussion on this topic). In most cases, using simple $F s t$ values complicates the distinction between the effects of the landscape on effective population size (through genetic drift) and the effects of the landscape on dispersal (gene flow). To overcome these confounding effects, new population genetics methods were recently developed to obtain more reliable values of gene flow. The widely used isolation with migration model (IM and IMa) uses coalescent theory to compute joint estimations of effective population sizes, divergence times, and genetic exchanges, with the advantage of taking into account asymmetry in gene flow (Hey \& Nielsen, 2004, 2007). Other coalescentbased methods have been developed in software such as Migrate (Beerli \& Palczewski, 2010) and Mimar (Becquet \& Przeworski, 2007). The Bayesian framework is also widely employed either to detect recent dispersal events using assignment tests [see Structure (Pritchard, Stephens \& Donnelly, 2000) and the Bayesian criteria used in Geneclass (Piry et al., 2004)] or to reconstruct more complex scenarios using approximate Bayesian computations ( $A B C$ methods, see review in Beaumont, 2010). Rather than choosing one of these approaches, we suggest using a combination of these population genetics methods, carefully chosen given the demography of the study species, to reduce the uncertainty in gene flow estimation (this approach was also suggested 
by Marko \& Hart, 2011). We also suggest that combining empirical data with simulation tools should greatly improve gene flow estimates from genetic data. In a landscape genetics framework, the use of computer simulations is particularly valuable when empirical data fail to match basic assumptions underlying available methods (e.g. asymmetric gene flow, population at non-equilibrium state, etc.), which is often the case in fragmented populations (Epperson et al., 2010).

The next step is to use the estimate of gene flow in a landscape genetics framework. Landscape genetics aims to use genetic data to document the effect of particular landscape features (e.g. degree of fragmentation, altitude, presence of a corridor ...) on gene flow. A growing number of tools are dedicated to this goal. A brief list includes isolationby-resistance (McRae, 2006), Bayesian methods to detect landscape effects (e.g. Faubet \& Gaggiotti, 2008), model selection (Shirk et al., 2010), correlations between genetic distances and landscape structures (e.g. Jaquiéry et al., 2011) or spatial regression (Spear \& Storfer, 2008), each having its own pros and cons (see Storfer et al., 2010, and references therein for a complete review). Moreover, the review of Storfer et al. (2010) clearly shows how the implementation of management decisions will benefit from studies of gene flow, given the variability in effects of habitat fragmentation on population structure and dispersal. Besides, landscape genetics studies are also useful for revealing counterintuitive features that facilitate gene flow (Storfer et al., 2010).

Future research will probably gradually turn to landscape genomics, an area that should benefit greatly from the opportunity to accumulate a large number of new markers using next-generation sequencing (NGS) (see Schwartz et al., 2010, for a review). Apart from simply increasing the power in the estimates of gene flow by increasing the number of loci available, landscape genomics allow the combination of neutral markers and loci putatively under selection. Promising avenues for NGS include the study of variation in adaptive genes in response to environmental processes (Schwartz et al., 2010), and the study of variation in genes implied in species' responses to rapid landscape changes. Comparison of the variation in neutral markers, which reflect non-adaptive landscape properties, with variations in selected loci can indeed reveal the underlying patterns of natural selection associated with some landscape characteristics [see the review of Schwartz et al. (2010), and an example for humans in Prugnolle, Manica \& Balloux (2005a) and Prugnolle et al. (2005b)]. As a result, future research incorporating NGS data into landscape genomics will improve our comprehension of the ways in which heterogeneity of natural landscapes moulds the genomes of organisms (Lowry, 2010).

\section{(7) Practical implementation of connectivity assessments}

The critical point that will limit the use of genetic tools in the assessment of landscape connectivity is their financial cost. In the establishment of the French Ecological Network ('Trame Verte et Bleue'), we recently budgeted the yearly monitoring (with genetic tools) of a network of 20 populations of a single species, where 30 individuals per population will be genotyped at 12 microsatellite loci grouped into 3 multiplexes (to reduce the cost of genotyping). Assuming that microsatellite sequences have been previously isolated and characterized, and including manpower and operating costs, we calculated a cost of approximately $26000 € /$ year. This high cost makes the application of genetic tools to all species of conservation concern in a given area near impossible. We must therefore carefully select species and focus on umbrella species (Lambeck, 1997; Caro \& O'Doherty, 1999; Caro, Eadie \& Sih, 2005), which are considered to be representative of the ecosystem in which they live (see section IV.2). Annual monitoring of a given network is obviously not always required: if the level of inbreeding in local populations is not a problem, a 'sentinel' survey of the network could be carried out periodically, the frequency of which would depend on the generation time of the species under investigation and on the frequency of disturbances within the landscape. As mentioned above, gene flow surveys benefit from being coupled with monitoring of individual movements, to gain insights into the effect of landscape structure on effective dispersal. However, the monitoring of individual movements represents an extra financial cost, sometimes even higher than the budget required for genetic analyses. When only one survey can be financed, we recommend opting for the genetic approach as improving efficient dispersal is the ultimate goal of the implementation of ecological networks.

\section{FROM LANDSGAPE CONNEGTIVITY TO EGOLOGIGAL NETWORKS}

The insight that species conservation should be thought of regionally rather than locally has generated national and international interest in the design of linkage strategies, even leading to the upscaling of connectivity from landscapes to region (Beier et al., 2011). Unfortunately, these interests have focused more on landscape connectivity, and almost entirely on structural connectivity, rather than on individual dispersal, even though dispersal is at the centre of metapopulation functioning. Existing landscape planning simulation tools, such as Marxan with zones or Zonation that are designed to build ecological networks use rules like the selection of the areas that maximize species diversity (Moilanen, 2007), or the existence of a threshold number of populations per species in the network (Ball, Possingham \& Watts, 2009). Given the imprecision of such multi-specific criteria (species diversity or threshold number of populations per species), only crude estimates of connectivity are implemented in these methods, and the end product is static. However, it is well documented that the extinction of local populations will always precede the extinction of a species in the landscape (e.g. Ceballos \& Ehrlich, 2002). Moreover, these landscape planning simulation tools are based on the implicit assumption that metapopulation functioning will emerge in connected 
areas. The intrinsic complexity of the dispersal process, including its spatiotemporal variability, clearly challenges this assumption. The inherent consequence of omitting or imperfectly addressing the dispersal process in the development of conservation strategies is that many human and financial efforts have been invested in planning measures aimed at linking similar ecosystems, without considering the functionality of such artificial linkages in terms of habitat selection and dispersal. Such efforts are illustrated by the production of maps supposedly capturing ecological networks at regional, national and transnational scales. However, even if this end product is cosmetic and has thus an intuitively attractive impact, its practical use and efficiency remain questionable. Here we propose that genetic tools may serve as a basis to implement functional networks using umbrella species.

\section{(1) From single- to multiple-species networks}

How does one conciliate the ecological requirements of different organisms in the same landscape? Building functional ecological networks is important for the conservation of many species. Using genetic tools together with data on individual movements (to account for the potential effect of landscape structure on effective dispersal, see above), it is possible to build functional networks of local populations for a given species in a given landscape with a reasonable probability of success. Upscaling such singlespecies networks to viable multi-species networks is a much more questionable approach. The methodology we propose here is based on a different approach than the classically used optimization of structural connectivity, but is far from being an absolute solution to habitat loss and landscape fragmentation. Its advantage is that the resulting ecological networks should be more functional than those based on the structural connectivity of protected areas.

As mentioned above, landscapes are inherently heterogeneous due to the existence of environmental gradients, and consist of a mosaic of various ecosystems linked by the dynamics of perturbations and ecological successions (e.g. Pickett \& White, 1985; Blondel, 1987). The basic idea is (i) to identify wide groups of natural and semi-natural ecosystems in the landscape of interest (i.e. peat bogs, deciduous forests, wet hay meadows, calcareous grasslands, etc., in terrestrial landscapes; coral reefs, kelp forests, estuaries, etc., in seascapes; wetlands, ponds, backwaters, floodplains, creeks, etc., in fresh water; Fig. 3, Step I), and in each of these groups, to select a handful of umbrella species that can be considered as representative of the ecosystem (e.g. Lambeck, 1997; Caro \& O’Doherty, 1999; Caro et al., 2005, and see below for a discussion of the characteristics of umbrella species). (ii) To map the habitats and their quality, as well as the local populations of each of these species in the landscape of interest (Fig. 3, Step II). A possible strategy would be to perform detailed field work, including habitat characterization and estimation of population sizes using dedicated methods (direct counts, reliable sampling methods like capture mark recapture or transects). (iii) To test for the

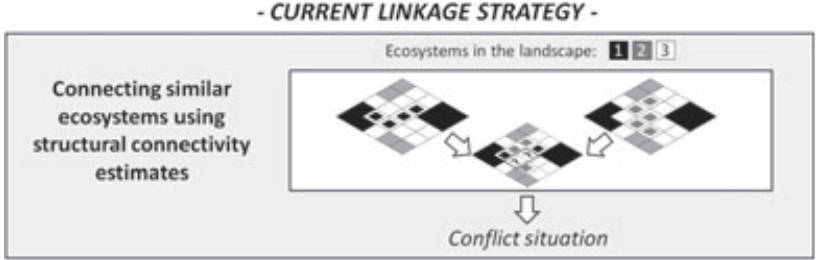

- PROPOSED METHOLOGY -

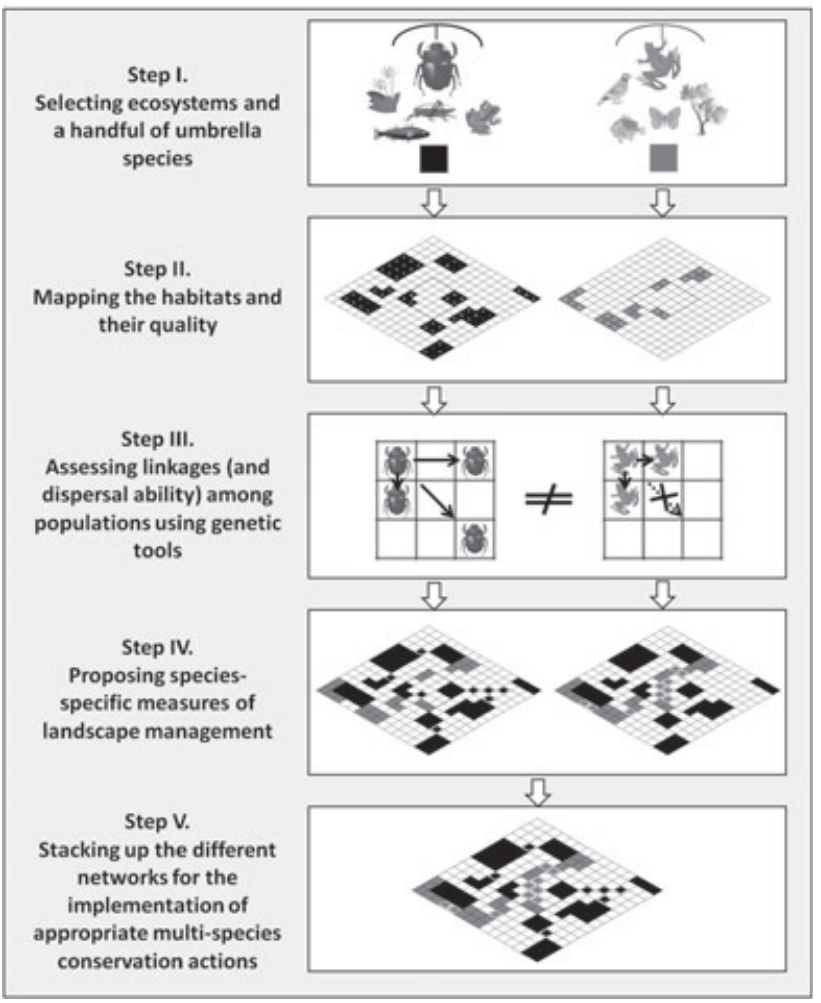

Fig. 3. Comparison of linkage strategy based on structural connectivity estimates (A) and the methodology we propose here (B), with the five successive steps leading to the design of functional multi-specific ecological networks.

linkages among these populations using genetic tools (Fig. 3, Step III). (iv) To propose measures of landscape management that will improve their functionality based on the resulting gene flow and effective population size estimates (Fig. 3, Step IV). (v) The ecological network in the area of interest will thus emerge from the stacking up of individual networks designed for umbrella species living in different ecosystems (Fig. 3, Step V). This basic procedure of stacking up a suite of networks for umbrella species representative of different ecosystems was used to design the Swiss national ecological network (Berthoud, Lebeau \& Righetti, 2004) and is currently being implemented in France to design the French national ecological network (Allag-Dhuisme et al., 2010). However, in both cases, step 3 (the validation of the functionality of networks by genetic tools) is missing, which clearly limits the functionality of the proposed ecological network. Conflicts among species from the same ecosystem or among ecosystems are expected to occur when different networks overlap. 
Their resolution will clearly be case-specific and will require the analysis of the conservation status of the species as well as their ecological characteristics. Using population viability analyses (e.g. Beissinger \& McCullough, 2002; Morris $\&$ Doak, 2002), quantitative comparisons of alternative scenarios of landscape management are possible. The use of multi-agent models with procedures of conflict solution (e.g. Konak, Coit \& Smith, 2006) to compare these predictions is a promising research avenue.

\section{(2) Selection of umbrella species}

How can one select the best umbrella species for a community? Defining ecological networks, i.e. habitat quality and connectivity, for a whole community on the basis of habitat selection and dispersal of a handful of species is a risky generalization. The conservation actions that promote the persistence of umbrella species in the landscape must also promote the persistence of (many, if not all) other species of the ecosystem. Detailed comparisons of habitat selection in ecological siblings most often reveal that even if species share the same ecosystem, their respective ecological requirements may be markedly different (e.g. Wellenreuther, Syms \& Clements, 2007). Turlure et al. (2009) analyzed how two butterfly species sharing the same host plants and living in the same habitat type, as defined by ecosystem classifications like CORINE-Biotope and EUNIS, use different functional habitats (Dennis, Shreeve \& Van Dyck, 2003). They showed that habitat definition and quality were not transferable from one species to the other, even if they shared many ecological features. Only a few studies have assessed the functionality of habitat networks in different species. Comparing three specialist butterfly species living in chalk grasslands, Baguette, Petit \& Queva (2000) showed that population structure and dispersal patterns were markedly different. Relationships between dispersal and usual surrogates of habitat quality like patch areas cannot be applied generally, just like dispersal kernels describing how the frequency of dispersal events decays with distance were markedly different among species. Fric et al. (2010) analyzed four species of butterfly specialists living in wet hay meadows and reached the same conclusion, even if dispersal patterns in this case were more alike in taxonomically related species. Doerr, Doerr \& Davies (2011b) showed that the dispersal behaviour of a forest passerine can predict the functional connectivity of the landscape for several other forest bird species. Finally, Blanchet et al. (2010) quantified the impact of weirs on the genetic diversity of four freshwater fish species. They showed that two species were strongly and negatively affected by the presence of such obstacles, which implied that dispersal along the river network in these two species was much more affected by the presence of weirs than in the two other species. They concluded that restoration programmes aimed at improving connectivity in river networks should first consider the two most sensitive species, which should be regarded as umbrella species (Blanchet et al., 2010).

The most critical point of the overall approach is thus the selection of umbrella species. Several key parameters can help solve this crucial question (e.g. Lambeck, 1997). The basic principle is that those species that can do the big things can do the little things as well. Accordingly, species with the highest exigencies in terms of habitat quality (for instance the more specialized) and in terms of dispersal (for instance those with the lowest dispersal power) should be preferred over generalist or highly mobile species. Specialist species with complex life cycles and low dispersal rates/dispersal distances are expected to be more demanding in landscape connectivity. This requires basic knowledge of the life histories of the species in the community, including specialization cues for habitat selection, dispersal mode, and dispersal distances and frequencies. The analysis of how life histories are interrelated with dispersal in communities within a particular taxonomic group (using the method developed by Stevens et al., 2012) could be a promising avenue in the identification of reliable umbrella species.

\section{GONGLUSIONS}

(1) The linkage strategy aimed at favouring metapopulation functioning depends on dispersal, which is a spatially and temporally variable process. We suggest that structural connectivity estimates are unable to capture this variability. We emphasize that the simulation tools aimed at planning ecological networks make the implicit and untested assumption that species living in spatially close ecosystems function as metapopulations.

(2) We highlight that the design of functional linkages in a given landscape for a given species is scientifically sound only if the dispersal and habitat selection of the studied species in the studied landscape are reasonably well known.

(3) We propose a simplified method in five steps as a possible approach to designing reliable ecological networks: (i) to identify groups of ecosystems within landscapes, and to select umbrella species for each group; (ii) to map habitat patches and populations in the landscape and to assess habitat quality; (iii) to assess linkages in the landscape using genetic tools; (iv) to propose measures of landscape management that will improve their functionality based on the resulting gene flow and effective population size estimates; $(v)$ the ecological network in the area of interest will then emerge from the stacking up of individual networks designed for umbrella species living in different ecosystems. We expect that ecological networks as determined by our approach will be more functional than structural linkages of heterogeneous areas at large, regional, national or even transnational spatial scales, from which management rules are then downscaled to the landscape level.

(4) Upscaling landscape connectivity from metapopulations to communities is a questionable process that conservation biologists are forced to accommodate because there are currently few alternative options, which rely on critical implicit assumptions. 


\section{ACKNOWLEDGEMENTS}

We warmly thank two reviewers for their helpful comments that helped us to improve the quality of this paper. We also thank Radika J. Michniewicz for thorough editing. M. B. and D. L. are funded by the Agence Nationale de la Recherche, via the programs open call DIAME (dispersal and metapopulation), sixth extinction MOBIGEN, and EU FP6 Biodiversa ERANET TenLamas, and by the EU FP7 SCALES project (project no. 226852). C. T. is funded by postdoctoral grants from the FNRS- F. S. R. M. B., S. B., D. L. and V. S. are part of the Laboratoire d'Excellence TULIP (ANR-10-LABX-41).

\section{REFERENGES}

Adriaensen, F., Chardon, J. P., De Blust, G., Swinnen, E., Villalba, S., Gulinck, H. \& Matthysen, E. (2003). The application of 'least-cost' modelling as a functional landscape model. Landscape and Urban Planning 64, 233-247.

Alagador, D., Trivino, M., Cerdeira, J. O., Bras, R., Cabeza, M. \& Araujo, M. B. (2012). Linking like with like: optimising connectivity between environmentallysimilar habitats. Landscape Ecology 27, 291-301.

Allag-Dhuisme, F., Amsallem, J., Barthod, C., Deshayes, M., Graffin, V., Leffeuvre, C., Salles, E., Barnetche, C., Brouard-Masson, J., Delaunay, A., Garnier, C. C. \& Trouvilliez, J. (2010). Choix Stratégiques de Nature à Contribuer à la Préservation et à la Remise en Bon état des Continuités Ecologiques - Premier Document en Appui à la Mise en Euvre de la Trame verte et Bleue en France. Proposition Issue du Comité Opérationnel Trame Verte et Bleue. MEEDDM ed., Paris.

Allen, T. F. H. (1998). The landscape level is dead: persuading the family to take it off the respirator. In Ecological Scale. Theory and Applications (eds D. L. Peterson and V. T. Parker). Columbia University Press, New-York.

Allen, R. M., Buckley, Y. M. \& Marshall, D. J. (2008). Offspring size plasticity in response to intraspecific competition: an adaptive maternal effect across life-history stages. The American Naturalist 171, 225-237.

Alp, M., Keller, I., Westram, A. M. \& Robinson, C. T. (2012). How river structure and biological traits influence gene flow: a population genetic study of two stream invertebrates with differing dispersal abilities. Freshwater Biology 57, 969-981.

Baguette, M., Clobert, J. \& Schtickzelle, N. (2011). Metapopulation dynamics of the bog fritillary butterfly: experimental changes in habitat quality induced negative density-dependent dispersal. Ecography 34, 170-176.

Baguette, M., Petit, S. \& Queva, F. (2000). Population spatial structure and migration of three butterfly species within the same habitat network: consequences for conservation. Fournal of Applied Ecology 37, 100-108.

BAGUeTte, M. \& VAN DyCK, H. (2007). Landscape connectivity and animal behavior: functional grain as a key determinant for dispersal. Landscape Ecology 22, 1117-1129.

BAKer, R. R. (1978). The Evolutionary Ecology of Animal Migration. Holmes \& Meier Publishers, New York.

Ball, I. R., Possingham, H. P. \& Watts, M. E. (2009). Marxan and relatives: software for spatial conservation prioritization. In Spatial Conservation Prioritization: Quantitative Methods and Computational Tools (eds A. Moilanen, K. A. Wilson and H. P. Possingham), pp. 185-195. Oxford University Press, Oxford.

Bay, L. K., Caley, M. J. \& Crozier, R. H. (2008). Meta-population structure in a coral reef fish demonstrated by genetic data on patterns of migration, extinction and re-colonisation. BMC Evolutionary Biology 8, 248.

Beaumont, M. A. (2010). Approximate Bayesian computation in evolution and ecology. Annual Review of Ecology, Evolution, and Systematics 41, 379-406.

Becquet, C. \& Przeworski, M. (2007). A new method to estimate parameters of speciation model, with application to apes. Genome Research 17, 1505-1519.

Beerli, P. \& Palczewski, M. (2010). Unified framework to evaluate panmixia and migration direction among multiple sampling locations. Genetics 185, 313-326.

BeIER, P. \& Noss, R. F. (1998). Do habitat corridors provide connectivity? Conservation Biology 12, 1241-1252.

Beier, P., Spencer, W., Baldwin, R. F. \& MCrae, B. H. (2011). Toward best practices for developing regional connectivity maps. Conservation Biology 25, 879-892.

Beissinger, S. R. \& McCullough, D. R. (2002). Population Viability Analyses. The University of Chicago Press, Chicago \& London.

Bennett, A. F. (1999). Linkages in the Landscape: The Role of Corridors and Connectivity in Wildlife Conservation. International Union for Conservation of Nature and Natural Resources, Gland and Cambridge.
Berthoud, G., Lebeau, R. P. \& Righetti, A. (2004). Réseau écologique national REN. Rapport final. Cahier de l'environnement 73. Office fédéral de l'environnement, des forêts et du paysage, Berne.

Bilton, D. T., Freeland, J. R. \& Okamura, B. (2001). Dispersal in freshwater invertebrates. Annual Review of Ecology and Systematics 32, 159-181.

Blanchet, S., Rey, O., Etienne, R. S., Lek, S. \& Loot, G. (2010). Species-specific responses to landscape fragmentation: implications for management strategies. Evolutionary Applications 3, 291-304.

Blondel, J. (1987). From biogeography to life history theory: a multithematic approach illustrated by the biogeography of vertebrates. Fournal of Biogeography 14, $405-422$.

Bonte, D., Van Dyck, H., Bullock, J. M., Coulon, A., Delgado, M., Gibbs, M., Lehouck, V., Matthysen, E., Mustin, K., SaAstamoinen, M., Schtickzelle, N., Stevens, V. M., Vandewoestijne, S., Baguette, M., Barton, K., Benton, T. G., Chaput-Bardy, A., Clobert, J., Dytham, C., Hovestadt, T., Meier, C. M., Palmer, S., Turlure, C. \& Travis, J. M. J. et al. (2012). Costs of dispersal. Biological Reviews 87, 290-312.

Boudjemadi, K., Lecomte, J. \& Clobert, J. (1999). Influence of connectivity on demography and dispersal in two contrasting habitats: an experimental approach. Journal of Animal Ecology 68, 1207-1224.

Bowler, D. E. \& Benton, T. G. (2005). Causes and consequences of animal dispersal strategies: relating individual behaviour to spatial dynamics. Biological Reviewes 80, $205-225$.

Brook, B. W., Tonkyn, D. W., Q'Grady, J. J. \& Frankham, R. (2002). Contribution of inbreeding to extinction risk in threatened species. Conservation Ecology 6, 16.

Broquet, T. \& Petit, E. J. (2009). Molecular estimation of dispersal for ecology and population genetics. Annual Review of Ecology, Evolution, and Systematics 40, 193-216.

Broquet, T., Ray, N., Petit, E., Fryxell, J. M. \& Burel, F. (2006). Genetic isolation by distance and landscape connectivity in the American marten (Martes americana). Landscape Ecology 21, 877-889.

Brown, J. A. \& Kodric-Brown, A. (1977). Turnover rates in insular biogeography: effect of immigration on extinction. Ecology 58, 445-449.

Burkey, T. V. (1997). Metapopulation extinction in fragmented landscapes: using bacteria and protozoa communities as model ecosystems. The American Naturalist 150, $568-591$.

Burton, O. J., Phillips, B. L. \& Travis, J. M. J. (2010). Trade-offs and the evolution of life-histories during range expansion. Ecology Letters 13, 1210-1220.

Calabrese, J. M. \& Fagan, W. F. (2004). A comparison-shopper's guide to connectivity metrics. Frontiers in Ecology and the Environment 2, 529-536.

Campbell Grant, E. H., Lowe, W. H. \& Fagan, W. F. (2007). Living in the branches: population dynamics and ecological processes in dendritic networks. Ecology Letters 10, 165-175.

Campbell Grant, E. H., Nichols, J. D., Lowe, W. H. \& Fagan, W. F. (2010). Use of multiple dispersal pathways facilitates amphibian persistence in stream networks. Proceedings of the National Academy of Sciences of the United States of America 107, 6936-6940.

Caro, T. M., Eadie, J. \& SiH, A. (2005). Use of substitute species in conservation biology. Conservation Biology 19, 1821-1826.

CARo, T. M. \& O'Doherty, G. (1999). On the use of surrogate species in conservation biology. Conservation Biology 13, 805-814.

Carrara, F., Altermatt, F., Rodriguez-Iturbe, I. \& Rinaldo, A. (2012). Dendritic connectivity controls biodiversity patterns in experimental metacommunities. Proceedings of the National Academy of Sciences of the United States of America 109, 5761-5766.

Ceballos, G. \& Ehrlich, P. R. (2002). Mammal population losses and the extinction crisis. Science 296, 904-907.

Chapman, B. B., Hulthén, K., Blomoyist, D. R., Hansson, L. A., Nilsson, J A., Brodersen, J., Nilsson, P. A., Skov, C. \& Brönmark, C. (2011). To boldy go: individual differences in boldness influence migratory tendency. Ecology Letters 14, $871-876$.

Chetkiewicz, C. L. B., Clair, C. C. S. \& Boyce, M. S. (2006). Corridors for conservation: integrating pattern and process. Annual Review of Ecology, Evolution, and Systematics 37, 317-342.

Clobert, J., Danchin, E., Dhondt, A. A. \& Nichols, J. D. (2001). Dispersal. Oxford University Press, Oxford.

Clobert, J., De Fraipont, M. \& Danchin, E. (2008). Evolution of dispersal. In Behavioural Ecology (eds E. Danchin, L. A. Giraldeau and F. Cezilly), pp. 323-353. Oxford University Press, Oxford.

Clobert, J., Ims, R. A. \& Rousset, F. (2004). Causes, mechanisms and consequences of dispersal. In Ecology, Genetics and Evolution of Metapopulations (eds I. HANSKI and O. E. Gaggiotti), pp. 307-335. Academic Press, Amsterdam.

Clobert, J., Le Galliard, J. F., Cote, J., Meylan, S. \& Massot, M. (2009). Informed dispersal, heterogeneity in animal dispersal syndromes and the dynamics of spatially structured populations. Ecology Letters 12, 197-209.

Costello, C., Rassweiler, A., Siegel, D., De Leod, G., Michelie, F. \& RosenberG, A. (2010). The value of spatial information in MPA network design. Proceedings of the National Academy of Sciences of the United States of America 107, 18294-18299. 
Cote, J., Clobert, J., Brodin, T., Fogarty, S. \& Sih, A. (2010). Personalitydependent dispersal: characterization, ontogeny and consequences for spatially structured populations. Philosophical Transactions of the Royal Society B: Biological Sciences 365, 4065-4076.

Cottenie, K. \& De Meester, L. (2003). Connectivity and cladoceran species richness in a metacommunity of shallow lakes. Freshwater Biology 48, 823-832.

Coulon, A., Cosson, J.-F., Angibault, J. M., Cargnelutti, B., Galan, M., Morellet, N., Petit, E., Aulagnier, S. \& Hewison, A. J. (2004). Landscape connectivity influences gene flow in a roe deer population inhabiting a fragmented landscape: an individual-based approach. Molecular Ecology 13, 2841-2850.

Cowen, R. K., Paris, C. B. \& Srinivasan, A. (2006). Scaling of connectivity in marine populations. Science $\mathbf{3 1 1}, 522-527$.

Crooks, K. R. \& Sanjayan, M. (2006). Connectivity Conservation. Cambridge University Press, Cambridge.

Cushman, S. A., McKelvey, K. S., Hayden, J. \& Schwartz, M. K. (2006). Gene flow in complex landscapes: testing multiple hypotheses with causal modeling. The American Naturalist 168, 486-499.

DAhlgren, J. P. \& Ehrlén, J. (2005). Distribution patterns of vascular plants in lakes - the role of metapopulation dynamics. Ecography 28, 49-58.

Delattre, T., Burel, F., Humeau, A., Stevens, V. M., Vernon, P. \& Baguette, M. (2010). Dispersal mood revealed by shifts from routine to direct flights in the meadow brown butterfly Maniola jurtina. Oikos 119, 1900-1908.

Dennis, R., Shreeve, T. \& VAn Dyck, H. (2003). Towards a resource-based concept for habitat: a butterfly biology viewpoint. Oikos 102, 417-426.

Desrochers, A., Bélisle, M., Morand-Ferron, J. \& Bourque, J. (2011). Integrating GIS and homing experiments to study avian movement costs. Landscape Ecology 26, 47-58.

DiBacco, C., Levin, L. A. \& Sala, E. (2006). Connectivity in marine systems. In Connectivity Conservation (eds K. R. Crooks and M. A. SAnjayan), pp. 184-212. Cambridge University Press, Cambridge.

Dingemanse, N. J., Kazem, A. J. N., Réale, D. \& Wright, J. (2009). Behavioural reaction norms: animal personality meets individual plasticity. Trends in Ecology \& Evolution 25, 81-89.

Doerr, V. A. J., Barrett, T. \& Doerr, E. D. (2011a). Connectivity, dispersal behaviour and conservation under climate change: a response to Hodgson et al. Journal of Applied Ecology 48, 143-147.

Doerr, V. A. J., Doerr, E. D. \& Davies, M. J. (2011b). Dispersal behaviour of Brown Treecreepers predicts functional connectivity for several other woodland birds. Emu 111, 71-83.

Ducatez, S., Baguette, M., Stevens, V. M., Legrand, D. \& Fréville, H. (2012). Complex interactions between paternal and maternal effects: parental experience and age at reproduction affect fecundity and offspring performance in a butterfly. Evolution 66, 3558-3569.

Dudgeon, D., Arthington, A. H., Gessner, M. O., Kawabata, Z. I., Knowler, D. J., Leveque, C., Naiman, R. J., Prieur-Richard, A. H., Soto, D., Stiassny, M. L. J. \& Sullivan, C. A. (2006). Freshwater biodiversity: importance, threats, status and conservation challenges. Biological Reviews 81, 163-182.

Dytham, C. (2009). Evolved dispersal strategies at range margins. Proceedings of the Royal Society B: Biological Sciences 276, 1407-1413.

EdelaAr, P., Siepielski, A. M. \& Clobert, J. (2008). Matching habitat choice causes directed gene flow: a neglected dimension in evolution and ecology. Evolution 62, 2462-2472.

Epperson, B. K., Mcrae, B. H., Scribner, K., Cushman, S. A., Rosenberg, M. S., Fortin, M.-J., James, P. M. A., Murphy, M., Manel, S., Legendre, P. \& DALE, M. R. T. (2010). Utility of computer simulations in landscape genetics. Molecular Ecology 19, 3549-3564.

Epps, C. W., Wehausen, J. D., Bleich, V. C., Torres, S. G. \& Brashares, J. S. (2007). Optimizing dispersal and corridor models using landscape genetics. Fournal of Applied Ecology 44, 714-724.

Ewers, R. M. \& Didham, R. K. (2006). Confounding factors in the detection of species responses to habitat fragmentation. Biological Reviewes 81, 117-142.

Fagan, W. F. \& Holmes, E. E. (2006). Quantifying the extinction vortex. Ecology Letters 9, 51-60.

FAHrig, L. (2003). Effects of habitat fragmentation on biodiversity. Annual Review of Ecology, Evolution, and Systematics 34, 487-515.

Faubet, P. \& GagGiotti, O. E. (2008). A new bayesian method to identify the environmental factors that influence recent migration. Genetics 178, 1491-1504.

Faulks, L. K., Gilligan, D. M. \& Beheregaray, L. B. (2011). The role of anthropogenic vs. natural in-stream structures in determining connectivity and genetic diversity in an endangered freshwater fish, Macquarie perch (Macquaria australasica). Evolutionary Applications 4, 589-601.

Figuerola, J., Green, A. J. \& Michot, T. C. (2005). Invertebrate eggs can fly: evidence of waterfowl-mediated gene flow in aquatic invertebrates. The American Naturalist 165, 274-280

Foley, J. A., DeFries, R., Asner, G. P., Barford, C., Bonan, G., Carpenter, S. R., Chapin, F. S., Coe, M. T., Daily, G. C., Gibbs, H. K., Helkowski, J. H., Holloway, T., Howard, E. A., Kucharik, C. J., Monfreda, C.,
Patz, J. A., Prentice, I. C., Ramankutty, N., \& Snyder, P. K. et al. (2005). Global consequences of land use. Science 309, 570-574.

Forman, R. T. T. (1995). Land Mosaic. The Ecology of Landscapes and Region. Cambridge University Press, Cambridge.

Forman, R. T. T. \& Godron, M. (1986). Landscape Ecology. John Wiley \& Sons, New York.

Fortuna, M. A., Gomez-Rodriguez, C. \& Bascompte, J. (2006). Spatial network structure and amphibian persistence in stochastic environments. Proceedings of the Royal Society B: Biological Sciences 273, 1429-1434.

Fretwell, S. \& Lucas, H. L. (1970). On territorial behaviour and other factors influencing habitat distribution in birds. Acta Biotheoretica 19, 16-36.

Fric, Z., Hula, V., Klimova, M., Zimmermann, K. \& Konvicka, M. (2010). Dispersal of four fritillary butterflies within identical landscape. Ecological Research 25, 543-552.

Gaines, S. D., White, C., Carr, M. H. \& Palumbi, S. R. (2010). Designing marine reserve networks for both conservation and fisheries management. Proceedings of the National Academy of Sciences of the United States of America 107, 18286-18293.

Gilbert-Norton, L., Wilson, R., Stevens, J. R. \& Beard, K. H. (2010). A meta-analytic review of corridor effectiveness. Conservation Biology 24, 660-668.

Gilpin, M. \& Soule, M. E. (1986). Minimum viable populations: processes of species extinction. In Conservation Biology. The Science of Scarcity and Diversity (ed. M. E. SoulE), pp. 19-34. Sinauer, Sunderland.

Gotelli, N. J. \& TAYLOR, C. M. (1999). Testing macroecology models with stream-fish assemblages. Evolutionary Ecology Research 1, 847-858.

Griffen, B. D. \& Drake, J. M. (2008). A review of extinction in experimental populations. Fournal of Animal Ecology 77, 1274-1287.

Hall, L. S., Krausman, P. R. \& Morrison, M. L. (1997). The habitat concept and a plea for a standard terminology. Wildlife Society Bulletin 25, 173-182.

Hänfling, B. \& WeEtman, D. (2006). Concordant genetic estimators of migration reveal anthropogenically enhanced source-sink population structure in the River Sculpin, Cottus gobio. Genetics 173, 1487-1501.

Hanski, I. (1998). Metapopulation dynamics. Nature 396, 41-49.

HANSKI, I. (1999a). Habitat connectivity, habitat continuity, and metapopulations in dynamic landscapes. Oikos 87, 209-219.

Hanski, I. (1999b). Metapopulation Ecology. Oxford University Press, Oxford.

HANSKI, I. \& Gilpin, M. (1991). Metapopulation dynamics: brief history and conceptual domain. Biological fournal of the Linnean Society 42, 3-16.

Hanski, I. \& Gilpin, M. E. (1997). Metapopulation Biology, Ecology, Genetics, and Evolution. Academic Press, San Diego.

Hanski, I. \& Simberloff, D. (1997). The metapopulation approach, its history, conceptual domain, and application to conservation. In Metapopulation Biology. Ecology, Genetics, and Evolution (eds I. Hanski and M. Gilpin), pp. 5-26. Academic Press, San Diego.

Hey, J. \& Nielsen, R. (2004). Multilocus methods for estimating population sizes, migration rates and divergence time, with applications to the divergence of Drosophila pseudoobscura and D. persimilis. Genetics 167, 747-760.

Hey, J. \& NiELSEN, R. (2007). Integration within the Felsenstein equation for improved Markov Chain Monte Carlo methods in population genetics. Proceedings of the National Academy of Sciences of the United States of America 104, 2785-2790.

Hilty, J., Lidicker, W. Z. \& Merenlender, A. M. (2006). Corridor Ecology. The Science and Practice of Linking Landscapes for Biodiversity Conservation. Island Press, Washington.

Hitt, S., Pittman, S. J. \& Nemeth, R. S. (2011). Diel movements of fishes linked to benthic seascape structure in a Caribbean coral reef ecosystem. Marine Ecology Progress Series 427, 275-291.

Hodgson, J. A., Moilanen, A., Wintle, B. A. \& Thomas, C. D. (2011a). Habitat area, quality and connectivity: striking the balance for efficient conservation. Fournal of Applied Ecology 48, 148-152.

Hodgson, J. A., Thomas, C. D., Cinderby, S., Cambridge, H., Evans, P. \& Hill, J. K. (2011b). Habitat re-creation strategies for promoting adaptation of species to climate change. Conservation Letters 4, 289-297.

Holt, R. D. \& BARfield, M. (2001). On the relationship between the ideal free distribution and the evolution of dispersal. In Dispersal (eds J. Clobert, E. Danchin, A. Dhondt and J. D. Nichols), pp. 83-95. Oxford University Press, Oxford.

Ims, R. A. \& Yoccoz, N. G. (1997). Studying transfer processes in metapopulations: emigration, migration, and colonization. In Metapopulation Biology: Ecology, Genetics, and Evolution (eds I. HANSKI and M. E. GiLPIN), pp. 247-265. Academic Press, London.

JaquiÉry, J., Broquet, T., Hirzel, A. H., Yearsley, J. \& Perrin, N. (2011). Inferring landscape effects on dispersal from genetic distances: how far can we go? Molecular Ecology 20,692-705.

Johnson, J. A., Toepfer, J. E. \& Dunn, P. O. (2003). Contrasting patterns of mitochondrial and microsatellite population structure in fragmented populations of greater prairie-chickens. Molecular Ecology 12, 3335-3347.

Jongman, R. \& Pungetti, G. (2004). Ecological Networks and Greenways. Concepts, Design, Implementation. Cambridge University Press, Cambridge.

KaWECKI, T. J. \& Holt, R. D. (2002). Evolutionary consequences of asymmetric dispersal rates. The American Naturalist 160, 333-347. 
Kendall, B. E., BJørnstad, O. N., Bascompte, J., Keitt, T. H. \& Fagan, W. F. (2000). Dispersal, environmental correlation, and spatial synchrony in population dynamics. The American Naturalist 155, 628-636.

Knowles, L. L. (2009). Statistical phylogeography. Annual Review of Ecology, Evolution, and Systematics 40, 593-612.

Kокко, H. \& Lopez-Sepulcre, A. (2006). From individual dispersal to species ranges: perspectives for a changing world. Science 313, 789-791.

KonaK, A., Coit, D. W. \& SMith, A. E. (2006). Multi-objective optimization using genetic algorithms: a tutorial. Reliability Engineering and System Safety 91, 992-1007.

Lada, H., MACNAlly, R. \& TAYlor, A. C. (2008). Distinguishing past from present gene flow along and across a river: the case of the carnivorous marsupial (Antechinus flavipes) on southern Australian floodplains. Conservation Genetics 9, 569-580.

LAMBECK, R. J. (1997). Focal species: a multi-species umbrella for nature conservation. Conservation Biology 11, 849-856.

Lawler, J. J., Aukema, J. E., Grant, J. B., Halpern, B. S., Kareiva, P., Nelson, C. R., Ohleth, K., Olden, J. D., Schlaepfer, M. A., Silliman, B. R. \& Zaradic, P. (2006). Conservation science: a 20-year report card. Frontiers in Ecology and the Environment 4, 473-480.

Legrand, D., Guillaume, O., Baguette, M., Cote, J., Trochet, A., Calvez, O., Zajitschek, S., Zajitschek, F., Lecomte, J., Bénard, Q., Le Galliard, J.-F. \& Clobert, J. (2012). The Metatron: an experimental system to study dispersal and metaecosystem dynamics for terrestrial organisms. Nature Methods 9, 828-833.

Legrand, D., Stevens, V. M. \& Baguette, M. (2011a). Selection on the wing in Heliconius butterflies. BMC Genetics 12, 31.

Legrand, D., Vautrin, D., Lachaise, D. \& Cariou, M.-L. (2011b). Microsatellite variation suggests a recent fine-scale population structure of Drosophila sechellia, a species endemic of the Seychelles archipelago. Genetica 139, 909-919.

Legrand, D., Tenaillon, M. I., Matyot, P., Gerlach, J., Lachaise, D. \& CARIOU, M.-L. (2009). Species-wide genetic variation and demographic history of Drosophila sechellia, a species lacking population structure. Genetics 182, 1197-1206.

Lepetz, V., Massot, M., Chaine, A. S. \& Clobert, J. (2009). Climate warming and the evolution of morphotypes in a reptile. Global Change Biology 15, 454-466.

Levins, R. (1969). Some demographic and genetic consequences of environmental heterogeneity for biological control. Bulletin of the Entomological Society of America 15, $237-240$

Lowry, D. B. (2010). Landscape evolutionary genomics. Biology Letters 6, 502-504.

Madsen, T., Shine, R., Olsson, M. \& Wittzell, H. (1999). Conservation biology: restoration of an inbred adder population. Nature 402, 34-35.

Manel, S., Gaggiotti, O. \& Waples, R. (2005). Assignment methods: which approaches best address which biological questions? Trends in Ecology \& Evolution 20, $136-142$.

Manel, S., Joost, S., Epperson, B. K., Holderegger, R., Storfer, A., Rosenberg, M. S., Scribner, K., Bonin, A. \& Fortin, M. J. (2010). Perspective on the use of landscape genetics to detect genetic adaptive variation in the field. Molecular Ecology 19, 3760-3772.

Manel, S., Schwartz, M. K., Luikart, G. \& Taberlet, P. (2003). Landscape genetics: combining landscape ecology and population genetics. Trends in Ecology \& Evolution 18, 189-197.

Marko, P. B. \& HART, M. W. (2011). The complex analytical landscape of gene flow inference. Trends in Ecology \& Evolution 26, 448-456.

Matthysen, E. (2005). Density-dependent dispersal in birds and mammals. Ecography 28, 403-416.

Matthysen, E. (2012). Multicausality of dispersal. In Dispersal Ecology and Evolution (eds J. Clobert, M. Baguette, T. G. Benton and J. M. Bullock), pp. 3-18. Oxford University Press, Oxford.

Maynard Smith, J. (1989). Evolutionary Genetics. Oxford University Press, Oxford.

McСook, L. J., Ayling, T., Cappo, M., Choate, J. H., Evans, R. D., De Freitas, D. M., Heupel, M., Hughes, T. P., Jones, G. P., Mapston, B., Marsh, H., Mills, M., Molloy, F. J., Pitcher, C. R., Pressey, R. L., Russ, G. R., Sutton, S., Sweatman, H., Tobin, R., Wachenfeld, D. R. \& Williamson, D. H. et al. (2010). Adaptive management of the Great Barrier Reef: a globally significant demonstration of the benefits of networks of marine reserves. Proceedings of the National Academy of Sciences of the United States of America 107, 18278-18285.

McPeek, M. A. \& Holt, R. D. (1992). The evolution of dispersal in spatially and temporally varying environments. The American Naturalist 140, 1010-1027.

MCRAE, B. H. (2006). Isolation by resistance. Evolution 60, 1551-1561.

Michels, E., Cottenie, K., Neys, L., De Gelas, K., Coppin, P. \& De Meester, L. (2001). Geographical and genetic distances among zooplankton populations in a set of interconnected ponds: a plea for using GIS modeling of the effective geographical distance. Molecular Ecology 10, 1929-1938.

Moilanen, A. (2007). Landscape zonation, benefit functions and targetbased planning. Unifying reserve selection strategies. Biological Conservation 134, $571-579$

Mollanen, A. (2011). On the limitation of the graph-theoretic connectivity in spatial ecology and conservation. Fournal of Applied Ecology 48, 1543-1547.

Moilanen, A. \& Nieminen, M. (2002). Simple connectivity measures in spatial ecology. Ecology 83, 1131-1145.
Mokhtar-Jamai, K., Pascual, M., Ledoux, J.-B., Coma, R., Feral, J.-P., Garrbou, J. \& Aurelle, D. (2011). From global to local genetic structuring in the red gorgonian Paramuricea clavata: the interplay between oceanographic conditions and limited larval dispersal. Molecular Ecology 20, 3291-3005.

Morris, D. W. \& Diffendorfer, J. E. (2004). Reciprocating dispersal by habitatselecting white-footed mice. Oikos 107, 549-558.

Morris, D. W., Diffendorfer, J. E. \& Lundberg, P. (2004). Dispersal among habitats varying in fitness: reciprocating migration through ideal habitat selection. Oikos 107, 559-575.

Morris, W. F. \& DoAk, D. F. (2002). Quantitative Conservation Biology. Sinauer, Sunderland.

Morrissey, M. B. \& de Kerckhove, D. T. (2009). The maintenance of genetic variation due to asymmetric gene flow in dendritic metapopulations. The American Naturalist 174, 875-889.

Mueller, T. \& FAGAN, W. F. (2008). Search and navigation in dynamic environments from individual behaviors to population distributions. Oikos 117, 654-664.

Nathan, R., Getz, W. M., Revilla, E., Holyoak, M., Kadmon, R., Saltz, D. \& Smouse, P. E. (2008). A movement ecology paradigm for unifying organismal movement research. Proceedings of the National Academy of Sciences of the United States of America 105, 19052-19059.

OuborG, N. J. (1993). Isolation, population size and extinction: the classical and metapopulation approaches applied to vascular plants along the Dutch Rhinesystem. Oikos 66, 298-308.

Palmer, S. C. F., Coulon, A. \& Travis, J. M. J. (2011). Introducing a 'stochastic movement simulator' for estimating habitat connectivity. Methods in Ecology and Evolution 2, 258-268.

Parn, H., Jensen, H., Ringsby, T. H. \& Saether, B. E. (2009). Sex-specific fitness correlates of dispersal in a house sparrow metapopulation. Foumal of Animal Ecology 78, $1216-1225$.

Pauly, D., Christensen, C., Guénette, S., Pitcher, T. J., Sumaila, U. R., WAlters, C. J., WAtson, R. \& Zeller, D. (2002). Towards sustainability in world fisheries. Nature 418, 689-695.

Pease, K. M., Freedman, A. H., Pollinger, J. P., McCormack, J. E., Buermann, W., Rodzen, J., Banks, J., Meredith, E., Bleich, V. C., Schaefer, R. J., Jones, K. \& WAYNE, R. K. (2009). Landscape genetics of California mule deer (Odocoileu. hemionus): the roles of ecological and historical factors in generating differentiation. Molecular Ecology 18, 1848-1862.

Pereira, H. M., Leadley, P. W., Proença, V., Alkemade, R., Scharlemann, J. P. W., Fernandez-Manjarrés, J. F., Araújo, M. B., Balvanera, P., Biggs, R. Cheung, W. W. L., Chini, L., Cooper, H. D., Gilman, E. L., Guénette, S. Hurtt, G. C., Huntington, H. P., Mace, G. M., Oberdorff, T., Revenga, C., Rodrigues, P., Scholes, R. J., Sumaila, U. R., \& Walpole, M. et al. (2010) Scenarios for global biodiversity in the 21st century. Science 330, 1496-1501.

Pickett, S. T. A. \& White, P. S. (1985). The Ecology of Natural Disturbances and Patch Dynamics. Academic Press, New York.

Pimm, S. L., Diamond, J., Reed, T. M., Russel, G. J. \& Verner, J. (1993). Times to extinction for small populations of large birds. Proceedings of the National Academy of Sciences of the United States of America 90, 10871-10875.

Pimm, S. L. \& Raven, P. (2000). Extinction by numbers. Nature 403, 843-845.

Pimm, S. L., Russell, G. J., Gittleman, J. L. \& Brooks, T. M. (1995). The future of biodiversity. Science 269, 347-350.

Piry, S., Alapetite, A., Cornuet, J.-M., Paetkau, D., Baudouin, L. \& Estoup, A. (2004). GeneClass2: a software for genetic assignment and first-generation migrant detection. The fournal of Heredity 95, 536-539.

Pollux, B. J. A., Luteijn, A., Van Groenendael, J. M. \& Ouborg, N. J. (2009). Gene flow and genetic structure of the aquatic macrophyte Sparganium emersum in a linear unidirectional river. Freshwater Biology 54, 64-76.

Pritchard, J. K., Stephens, M. \& Donnelly, P. (2000). Inference of population structure using multilocus genotype data. Genetics 155, 945-959.

Prugnolle, F., Manica, A. \& Balloux, F. (2005a). Geography predicts neutral genetic diversity of human populations. Current Biology 15, R159-R160.

Prugnolle, F., Manica, A., Charpentier, M., Guegan, J. F., Guernier, V. \& Balloux, F. (2005b). Pathogen driven selection and worldwide HLA Class I diversity. Current Biology 15, $1022-1027$.

Raeymaekers, J., Raeymaekers, D., Koizumi, I., Geldof, S. \& Volckaert, F. (2009). Guidelines for restoring connectivity around water mills: a population genetic approach to the management of riverine fish. Fournal of Applied Ecology 46, 562-571.

Réale, D., Gallant, B. Y., Leblanc, M. \& Festa-Bianchet, M. (2000). Consistency of temperament in bighorn ewes and correlates with behaviour and life history. Animal Behaviour 60, 589-597.

REED, D. H. (2010). Albatrosses, eagles and newts, Oh My!: exceptions to the prevailing paradigm concerning genetic diversity and population viability? Animal Conservation 13, 448-457.

Rockstrom, J., Steffen, W., Noone, K., Persson, A., Chapin, F. S., Lambin, E. F., Lenton, T. M., Scheffer, M., Folke, C., Schellnhuber, H. J., Nykvist, B., de Wit, C. A., Hughes, T., van der Leeuw, S., Rodhe, H., Sorlin, S., Snyder, P. K., Costanza, R., Svedin, U., Falkenmark, M. Karlberg, L., Corell, R. W., Fabry, V. J., Hansen, J., Walker, B. Liverman, D., Richardson, K., 
Crutzen, P., \& Foley, J. A. et al. (2009). A safe operating space for humanity. Nature 461, 472-475.

Rodriguez, A. \& Delibes, M. (2003). Population fragmentation and extinction in the Iberian lynx. Biological Conservation 109, 321-331.

Ronce, O. (2007). How does it feel to be like a rolling stone? Ten questions about dispersal evolution. Annual Review of Ecology, Evolution, and Systematics 38, 231-253.

Ronce, O. \& Clobert, J. (2012). Dispersal syndromes. In Dispersal Ecology and Evolution (eds J. Clobert, M. Baguette, T. G. Benton and J. M. Bullock), pp. 119-138. Oxford University Press, Oxford.

Rothermel, B. B. \& Semlitsch, R. D. (2002). An experimental investigation of landscape resistance of forest versus old-field habitats to emigrating juvenile amphibians. Conservation Biology 16, 1324-1332.

Saccheri, I., Kuussaari, M., Kankare, M., Vikman, P., Fortelius, W. \& Hanski, I. (1998). Inbreeding and extinction in a butterfly metapopulation. Nature 392, 491-494.

Sawyer, S. C., Epps, C. W. \& Brashares, J. S. (2011). Placing linkages among fragmented habitats: do least-cost models reflect how animals use landscapes? Fournal of Applied Ecology 48, 668-678.

Schtickzelle, N., Joiris, A., Van Dyck, H. \& Baguette, M. (2007). Quantitative analysis of changes in movement behaviour within and outside habitat in a specialist butterfly. BMC Evolutionary Biology 7, 4 .

Schtickzelle, N., Mennechez, G. \& Baguette, M. (2006). Dispersal depression with habitat fragmentation in the bog fritillary butterfly. Ecology 87, 1057-1065.

Schwartz, M., Luikart, G., McKelvey, K. \& Cushman, S. (2010). Landscape genomics: a brief perspective. In Spatial Complexity, Informatics, and Wildlife Conservation (eds F. Huettmann and S. Cushman), pp. 165-174. Springer-Verlag, Berlin.

Shirk, A. J., Wallin, D. O., Cushman, S. A., Rice, C. G. \& Warheit, K. I. (2010). Inferring landscape effects on gene flow: a new model selection framework. Molecular Ecology 17, 3603-3619.

Simberloff, D., Farr, J. A., Cox, J. \& Mehlman, D. W. (1992). Movement corridors - conservation bargains or poor investments. Conservation Biology 6, 493-504.

Sinn, D. L., Apiolaza, L. A. \& MoltschaniwskyJ, N. A. (2006). Heritability and fitness-related consequences of squid personality traits. Fournal of Evolutionary Biology 19, $1437-1447$.

SLATKIn, M. (1987). Gene flow and the natural structure of natural populations. Science 236, 787-792.

Sork, V. L. \& WAITs, L. (2010). Contributions of landscape genetics - approaches, insights, and future potential. Molecular Ecology 19, 3489-3495.

Spear, S. F. \& STORFER, A. (2008). Landscape genetic structure of coastal tailed frogs (Ascaphus truei) in protected vs. managed forests. Molecular Ecology 17, 4642-4656.

Stamps, J. A. (2001). Habitat selection by dispersers: integrating proximate and ultimate approaches. In Dispersal (eds J. Clobert, E. Danchin, A. A. Dhondt and J. D. Nichols), pp. 230-242. Oxford University Press, Oxford.

Stenseth, N. C. \& Lidicker, W. Z. (1992). Animal Dispersal. Chapman and Hall, London.

Stevens, V. M. \& Baguette, M. (2008). Importance of habitat quality and landscape connectivity for the persistence of endangered natterjack toads. Conservation Biology 22, 1194-1204.

Stevens, V. M., Pavoine, S. \& Baguette, M. (2010a). Variation within and between closely related species uncovers high intra-specific variability in dispersal. PLOS ONE 5, e11123.

Stevens, V. M., Turlure, C. \& Baguette, M. (2010b). A meta-analysis of dispersal in butterflies. Biological Reviews 85, 625-642.

Stevens, V. M., Trochet, A., Van Dyck, H., Clobert, J. \& Baguette, M. (2012). How is dispersal integrated in life-histories? A quantitative analysis using butterflies. Ecology Letters 15, 65-73.

Stevens, V. M., Verkenne, C., Vandewoestijne, S., Wesselingh, R. A. \& BAGUetTe, M. (2006). Gene flow and functional connectivity in the natterjack toad. Molecular Ecology 15, 2333-2344.

Storfer, A., Murphy, M. A., Spear, S. F., Holderegger, R. \& Waits, L. P. (2010). Landscape genetics: where are we now? Molecular Ecology 19, 3496-3514.

Sundblad, G., Bergström, U. \& Sandström, A. (2011). Ecological coherence of marine protected area networks: a spatial assessment using species distribution models. Journal of Applied Ecology 48, 112-120.
SunNucks, P. (2000). Efficient genetic markers for population biology. Trends in Ecology Eं Evolution 15, 199-203.

Swift, T. L. \& Hannon, S. J. (2010). Critical thresholds associated with habitat loss: a review of the concepts, evidence, and applications. Biological Reviewes 85, 35-53.

Taylor, P. D., Fahrig, L., Henein, K. \& Merriam, G. (1993). Connectivity is a vital element of landscape structure. Oikos 68, 571-573.

TAYlor, P., FAhrig, L. \& WITH, K. A. (2006). Landscape connectivity: back to the basics. In Connectivity Conservation (eds K. Crooks and M. A. SAnJayan), pp. 29-43. Cambridge University Press, Cambridge.

Teske, P. R., Forget, F. R. G., Cowley, P. D., von der Heyden, S. \& Beheregaray, L. B. (2010). Connectivity between marine reserves and exploited areas in the philopatric reef fish Chrysoblephus laticeps (Teleostei: Sparidae). Marine Biology 157, 2029-2042.

Travis, J. M. J. \& Dytham, C. (1999). Habitat persistence, habitat availability and the evolution of dispersal. Proceedings of the Royal Society B: Biological Sciences 266, $723-728$.

Travis, J. M. J., Murrell, D. J. \& Dytham, C. (1999). The evolution of densitydependent dispersal. Proceedings of the Royal Society B: Biological Sciences 266, 1837-1842.

Turgeon, K., Robillard, A., Gregoire, J., Duclos, V. \& Kramer, D. L. (2010). Functional connectivity from a reef fish perspective: behavioral tactics for moving in a fragmented landscape. Ecology 91, 3332-3342.

Turlure, C., Baguette, M., Stevens, V. M. \& Maes, D. (2011). Species- and sexspecific adjustments of movement behavior to landscape heterogeneity in butterflies. Behavioral Ecology 22, 967-975.

Turlure, C., Van Dyck, H., Schtickzelle, N. \& Baguette, M. (2009). Resourcebased habitat definition, niche overlap and conservation of two sympatric glacial relict butterflies. Oikos 118, 950-960.

Turner, M. G. (2000). Disturbance and landscape dynamics in a changing world. Ecology 91, 2833-2849.

Urban, D. \& KeITT, T. (2011). Landscape connectivity: a graph-theoretic perspective. Ecology 82, 1205-1218.

Urban, D. L., Minor, E. S., Treml, E. A. \& Schick, R. S. (2009). Graph models of habitat mosaics. Ecology Letters 12, 260-273.

Vanschoenwinkel, B., Gielen, S., Vandewaerde, H., Seaman, M. \& Brendonck, L. (2008). Relative importance of different dispersal vectors for small aquatic invertebrates in a rock pool metacommunity. Ecography 31, 567-577.

Verbeylen, G., De Bruyn, L., Adriaensen, F. \& Matthysen, E. (2003). Does matrix resistance influence Red squirrel (Sciurus vulgaris L. 1758) distribution in an urban landscape? Landscape Ecology 18, 791-805.

VigniERI, S. N. (2005). Streams over mountains: influence of riparian connectivity on gene flow in the Pacific jumpingmouse (Zapus trinotatus). Molecular Ecology 14, $1925-1937$.

VitouseK, P. M., Mooney, H. A., Lubchenco, J. \& Melillo, J. M. (1997). Human domination of earth's ecosystems. Science 277, 494-499.

WANG, I. J. (2010). Recognizing the temporal distinctions between landscape genetics and phylogeography. Molecular Ecology 19, 2605-2608.

WANG, Y.-H., YANG, K.-C., BRIDGMAN, C. L. \& Lin, L.-K. (2008). Habitat suitability modelling to correlate gene flow with landscape connectivity. Landscape Ecology 23, $989-1000$.

Wellenreuther, M., Syms, C. \& Clements, K. D. (2007). Body size and ecological diversification in a sister species pair of triplefin fishes. Evolutionary Ecology 22, $575-592$.

Whitlock, M. C. \& McCauley, D. E. (1999). Indirect measures of gene flow and migration: Fst doesn't equal 1/(4Nm+1). Heredity 82, 117-125.

Wiens, J. A. (1997). Metapopulation dynamics and landscape ecology. In Metapopulation Biology. Ecology, Genetics, and Evolution (eds I. HANSki and M. GiLPIN), pp. 43-62. Academic Press, San Diego.

Wilson, D. S., Clark, A. B., Coleman, K. \& Dearstyne, T. (1994). Shyness and boldness in humans and other animals. Trends in Ecology \&o Evolution 9, $442-446$.

Wright, S. (1931). Evolution in Mendelian populations. Genetics 16, 97-159.

ZhanG, D. X. \& HewitT, G. M. (2003). Nuclear DNA analyses in genetic studies of populations: practice, problems and prospects. Molecular Ecology 12, 563-584.

(Received 16 December 2011; revised 18 October 2012; accepted 25 October 2012 ) 